\title{
Interphase cytogenetics in the cytodiagnosis of leptomeningeal metastases
}

Citation for published version (APA):

van Oostenbrugge, R. J. (1999). Interphase cytogenetics in the cytodiagnosis of leptomeningeal metastases. [Doctoral Thesis, Maastricht University]. Universiteit Maastricht. https://doi.org/10.26481/dis.19990625ro

Document status and date:

Published: 01/01/1999

DOI:

10.26481/dis.19990625ro

Document Version:

Publisher's PDF, also known as Version of record

\section{Please check the document version of this publication:}

- A submitted manuscript is the version of the article upon submission and before peer-review. There can be important differences between the submitted version and the official published version of record.

People interested in the research are advised to contact the author for the final version of the publication, or visit the DOI to the publisher's website.

- The final author version and the galley proof are versions of the publication after peer review.

- The final published version features the final layout of the paper including the volume, issue and page numbers.

Link to publication

\footnotetext{
General rights rights.

- You may freely distribute the URL identifying the publication in the public portal. please follow below link for the End User Agreement:

www.umlib.nl/taverne-license

Take down policy

If you believe that this document breaches copyright please contact us at:

repository@maastrichtuniversity.nl

providing details and we will investigate your claim.
}

Copyright and moral rights for the publications made accessible in the public portal are retained by the authors and/or other copyright owners and it is a condition of accessing publications that users recognise and abide by the legal requirements associated with these

- Users may download and print one copy of any publication from the public portal for the purpose of private study or research.

- You may not further distribute the material or use it for any profit-making activity or commercial gain

If the publication is distributed under the terms of Article $25 \mathrm{fa}$ of the Dutch Copyright Act, indicated by the "Taverne" license above, 


\section{Interphase cytogenetics in the}

cytodiagnosis of leptomeningeal metastases 


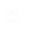

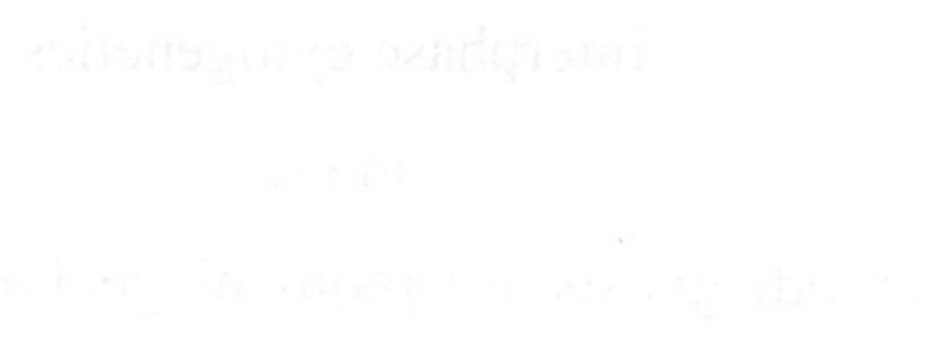

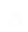




\section{Interphase cytogenetics}

in the

\section{cytodiagnosis of leptomeningeal metastases}

\section{PROEFSCHRIFT}

ter verkrijging van de graad van doctor aan de Universiteit Maastricht, op gezag van de Rector Magnificus, Prof. Dr. A.C. Nieuwenhuijzen Kruseman volgens het besluit van het College van Decanen, in het openbaar te verdedigen op vrijdag 25 juni 1999 om 16.00 uur door

ROBERT JAN VAN OOSTENBRUGGE 


\section{PROMOTORES:}

Prof. dr. J. Troost

Prof. dr. F.C.S. Ramaekers

CO-PROMOTORES:

Dr. A. Twijnstra

Dr. A.H.N. Hopman

\section{BEOORDELINGSCOMMISSIE:}

Prof. dr. J.P.M. Geraedts (voorzitter)

Prof. dr. J.J. Heimans (Vrije Universiteit Amsterdam)

Prof. dr. H.W.M. Steinbusch

Dr. D. Troost (Universiteit van Amsterdam)

Prof. dr. J. Wagstaff

This thesis was prepared at the Department of Neurology, University Hospital Maastricht, and at the Department of Molecular Cell Biology \& Genetics, Maastricht University, The Netherlands.

The studies and the publication of this thesis were financially supported by the Dutch Cancer Society (Nederlandse Kankerbestrijding - Koningin Wilhelmina Fonds), Amsterdam, The Netherlands.

Cover design by S. Graatsma.

Copyright: R.J. van Oostenbrugge, 1999. 
EEN ZEKERE DIAGNOSE VORMT DE BASIS VOOR DE THERAPIE

Voor Sonja 



\section{CONTENTS}

CHAPTER 1 In situ hybridization: a possible diagnostic aid in leptomeningeal metastases

CHAPTER 2 Leptomeningeal metastases in patients with solid and hematologic malignancies Presenting features and value of diagnostic procedures

CHAPTER 3 The use of poly-L-lysine coated slides for cytospinning of cerebrospinal fluid (CSF) increases the number of cells without improvement of the sensitivity of CSF cytology

CHAPTER 4 Detection of malignant cells in cerebrospinal fluid using fluorescence in situ hybridization

CHAPTER 5 Identical chromosomal aberrations are found in malignant cells in cerebrospinal fluid, and their corresponding leptomeningeal metastases and primary tumors

CHAPTER 6 The additional diagnostic value of fluorescence in situ hybridization in patients clinically suspected of leptomeningeal metastases

CHAPTER 7 Interphase cytogenetics increases the sensitivity of treatment response monitoring in patients with leptomeningeal metastases

CHAPTER 8 Summary and conclusions

Samenvatting

Dankwoord

Curriculum vitae

Publications 



\section{General introduction}

The infiltration of the leptomeninges by malignant cells, firstly described by Eberth ${ }^{1}$ in 1870 , is a relatively common neurological complication of cancer, and will be referred to in this thesis as leptomeningeal metastases (LMM). The exact incidence is unknown, although it can be found at autopsy in approximately $8 \%$ of cancer patients. While any systemic cancer type can metastasize to the leptomeninges, it occurs most often in patients with high-grade haematological malignancies and certain histological types of solid tumors like melanomas and adenocarcinomas of the lung and breast. ${ }^{2}$ Although the clinical features of LMM are extremely variable ${ }^{3}$, multifocal neurological symptoms in a patient known with cancer are regarded as diagnostic indicators. ${ }^{4}$ However, the detection of malignant cells in the cerebrospinal fluid (CSF) is crucial to establish a definitive diagnosis. Because early treatment of LMM can prevent neurological sequelae it is a necessity to diagnose LMM as soon as possible and preferably before neurological signs develop. The diagnostic yield of the first cytological examination of the CSF of a patient clinically suspected of LMM is, however, only moderately sensitive. This causes diagnostic time delay and discomfort for the patient because of the multiple lumbar punctures, which are needed to establish a diagnosis. The diagnostic assessment can not be improved by the use of additional tumor marker assays, immunocytochemistry and flow cytometric detection of aneuploidy. ${ }^{5}$ Therefore, a study was undertaken to detect chromosomal aberrations in the CSF cells by the use of in situ hybridization (ISH) for the identification of cancer cells. This technique, generally referred to as interphase cytogenetics ${ }^{6}$, refers to the visualization of structural or numerical chromosomal aberrations in interphase nuclei of single cells by means of labelled nucleic acid probes. It is an established method to study chromosomal aberrations for routine molecular cytogenetic diagnosis. The ISH-technique has proven diagnostic impact in certain malignant conditions ${ }^{7}$ and it was found to be of additional diagnostic value in classifying atypical cells in different types of body fluids. ${ }^{8}$ The goal of the present studies was to establish whether or not the ISH assay could be of additional value in the cytodiagnosis of CSF.

After establishing the diagnosis, treatment with radiotherapy and chemotherapy might be initiated. The response of the intra-thecal chemotherapy must be monitored accurately for several reasons. Firstly, treatment with intrathecally administered chemotherapy can be hazardous to the patient and the risk of therapy related complications increases with the duration of treatment. Secondly, an alternative treatment must be started to prevent neurological sequelae as soon it becomes obvious that the started treatment is not successful. Thirdly, the treatment might seem adequate due to false-negative results of cytological monitoring and will be stopped. This may then lead to an early relapse of disease. Ideally, response to treatment of a malignancy is monitored by reduction in size of the tumor with concomitant support by the clinical staging. ${ }^{9}$ Another parameter to asses response to treatment can be achieved by follow up of a highly specific tumor marker. In case of LMM all these parameters are, however, known to be weak predictors of response. ${ }^{2}$ 
Generally, tumor response is monitored by sequential cytological evaluation of the CSF, although the sensitivity of this test decreases during intrathecal therapy due to a decrease in cell number and the occurrence of cytomorphological changes.

\section{OUTLINE OF THIS STUDY}

The aim of this study was to improve the cytodiagnosis of CSF by use of the ISH technique in patients either clinically suspected of LMM or treated for LMM.

Before analyzing the potential diagnostic role of the ISH procedure in LMM, we reviewed the literature on the currently used tests to diagnose LMM (CHAPTER 1) and studied the clinical presentation and results of routine diagnostic tests like neuro-imaging, CSF cell count, and CSF total protein in a group of 45 patients with proven LMM (CHAPTER 2) in order to improve the diagnostic assessment in case of a negative first CSF cytology. The results were compared in patients with LMM from solid tumors and haematological malignancies to determine potential differences in the mode of clinical presentation or in the additional value of these diagnostic tests.

Also before applying the ISH protocol to CSF samples the cytological preparation needed improvement, since one of the problems often encountered in CSF cytology is the low number of cells present in the sample. It has been demonstrated that the sensitivity of CSF cytology increases when the cell number is increased by processing a larger volume of CSF. ${ }^{10}$ However, this is not always possible and therefore another approach is to optimize the number of cells that adhere to the slides by a better attachment of these cells to the slides after using a poly-L-lysine coating (CHAPTER 3).

Although several ISH protocols are available that can be applied to different tissues and cell suspensions", a next step in the adequate implementation of the ISH method to CSF cytology was to optimize the ISH protocol used and to solve pitfalls encountered. A feasibility study was therefore performed in a series of patients with either cytologically established diagnoses of LMM or with inflammatory neurological disease (CHAPTER 4). In order to conclude that the aberrant cells in the CSF were shed into the CSF from leptomeningeal infiltration and indeed do represent the malignant process, similarities in the chromosomal aberrations of the primary tumor and leptomeningeal infiltration versus the malignant cells in the CSF samples had to be confirmed (CHAPTER 5).

Once these technical problems were solved, clinically relevant problems in CSF cytology could be tackled. One of these problems concerns the efficiency of diagnosis, which is due to the moderate sensitivity of the first CSF cytology in patients clinically suspected of LMM. To date multiple lumbar punctures are often needed to establish a diagnosis, what causes time delay and discomfort for the patients. In CHAPTER 6 we therefore studied the additional diagnostic value of the ISH method in 45 patients clinically suspected of LMM with special emphasis on the first CSF sample.

Another clinical problem is the monitoring of response to therapy for LMM. Although this is primary a function of consecutive CSF cytology, the sensitivity of CSF routine cytology 
decreases during treatment due to a decrease of cell number and an induction of cytomorphological changes. We evaluated whether the sequential detection of a known numerical chromosomal aberration in malignant cells from the CSF samples by use of the ISH method could improve the evaluation of response to treatment in seven patients (CHAPTER 7).

\section{REFERENCES}

1. Eberth CJ. Zur Entwickelung des Epithelioms (Cholesteatoms) der Pia und der Lunge. Virchows Arch 1870;49:51-63.

2. Chamberlain MC. Leptomeningeal metastases. In: Vecht Ch J, ed. Handbook of Clinical neurology. Vol.25 (69): Neuro-Oncology, Part III. Amsterdam: Elsevier Science B.V., 1997:151-165.

3. Posner JB. Neurologic complications of cancer. Philadelphia: FA Davis Comp, 1995:143-171.

4. DeAngelis LM. Current diagnosis and treatment of leptomeningeal metastasis. J Neurooncol 1998;38:245-252.

5. Chamberlain MC. New approaches to and current treatment of leptomeningeal metastases. Curr Opin Neurol 1994;7:492-500.

6. Cremer T, Landegent J, Brückner A, et al. Detection of chromosome aberrations in the human interphase nucleus by visualization of specifec target DNAs with radioactive and nonradioactive in situ hybridization techniques: diagnosis of trisomy 18 with probe L1.84. Hum Genet 1986;74:346-352.

7. Wolfe KQ, Herrington CS. Interphase cytogenetics and pathology: a tool for diagnosis and research. J Pathol 1997;181:359-361.

8. Cajulis RS, Yu GH, Gokaslan ST, Hidvegi DF. Modified interphase cytogenetics technique as an adjunct in the analysis of atypical cells in body fluids. Diagn Cytopathol 1997;16:331-335.

9. Cleton FJ. Chemotherapy: general aspects. In: Peckham M, Pinedo H, Veronesi U, eds. Oxford textbook of oncology. New York: Oxford University Press Inc., 1995:445-453.

10. Glantz MJ, Cole BF, Glantz LK, et al. Cerebrospinal fluid cytology in patients with cancer: minimizing false-negative results. Cancer 1998;82:733-739.

11. Hopman AHN, Voorter CEM, Ramaekers FCS. Detection of genomic changes in cancer by in situ hybridization. Mol Biol Reports 1994;19:31-44. 


\section{CHAPTER 1}

IN Situ HYBRIDIZATION:

A POSSIBLE DIAGNOSTIC AID IN LEPTOMENINGEAL METASTASES

Adapted from:

RJ van Oostenbrugge, AHN Hopman, FCS Ramaekers and A Twijnstra.

In situ hybridization: A possible diagnostic aid in leptomeningeal metastasis. Journal of Neuro-Oncology 1998;38:127-133. 


\section{ABSTRACT}

In this review we discuss the clinical features and pathophysiology of leptomeningeal metastases (LMM), and elaborate on diagnostic tools for the detection of this serious complication of cancer. Because of the low sensitivity of the cytologic examination, new diagnostic approaches have been developed. The in situ hybridization technique may prove to be a reliable and early test for the detection of LMM. 


\section{INTRODUCTION}

Leptomeningeal metastases (LMM) are an important neurologic complication that may occur at any time during the course of systemic cancer. ${ }^{1,2}$ Although the exact incidence of LMM is not known, it is found at autopsy in $8 \%$ of cancer patients. ${ }^{3}$ While any systemic cancer can metastasize to the leptomeninges, it occurs most often in patients with non-Hodgkin lymphoma (7-15\%) and acute non-lymphocytic leukemia (5-15\%). Of the solid tumors, the adenocarcinomas are most likely to seed to the leptomeninges. For example, breast cancer accounts for $22-64 \%$ of LMM in solid tumors, followed by lung cancer (1-26\%) and malignant melanoma (7-15\%).

Several routes of neoplastic infiltration of the subarachnoid or ventricular cavity have been recognized. Kokkoris ${ }^{6}$ found that in the majority of cases of solid tumors, neoplastic cells reached the meninges by haematogenous, centripetal spread from adjacent bone metastases, mostly from the vertebral bodies. In leukemic patients, Price and Johnson ${ }^{7}$ and Azzarelli et $\mathrm{al}^{8}$ demonstrated the entry of neoplastic cells into the subarachnoid space via superficial cortical vessels. Dissemination of neoplastic cells into the cerebrospinal fluid (CSF) causing LMM from cerebral metastases is rare, since a fibrous reaction provoked by the cerebral tumor normally prevents such an entry. However, subependymal metastases may reach the ventricular surface, causing LMM. ${ }^{9}$

The clinical presentation of LMM is variable. Its neurological symptoms can be explained by invasion of neoplastic cells at three anatomical levels: the brain, the cranial nerves, and the spinal cord and nerve roots. The signs and symptoms of brain dysfunction due to LMM are mainly headache (40\%), gait problems (46\%), cognitive dysfunction (50\%) and, less frequently, seizures $(15 \%)$ or disturbances of consciousness $(13 \%))^{2,10,11}$ Cranial nerve abnormalities, mostly involving more than one nerve, are often found, resulting especially in disturbances of ocular movement or facial weakness. ${ }^{11,12}$

Spinal symptoms and signs can be found in $50 \%$ of the patients, with radicular pain and dysfunction at more than one level being most common. ${ }^{2,11}$

The pathophysiology of LMM is poorly understood. Some of the symptoms can be explained by the obstruction of normal CSF-flow due to obstruction of foramina of the fourth ventricle by neoplastic cells, causing hydrocephalus. ${ }^{2}$ Other explanations of the development of brain dysfunction include the metabolic competition between normal and malignant cells for essential nutritients like glucose $\mathrm{e}^{13}$, the parenchymal invasion of neoplastic cells along Virchow-Robin spaces ${ }^{4}$ and a diminished cerebral blood flow due to vascular changes caused by LMM. $^{14}$

At the microscopical level, LMM often consists of a diffuse infiltration of malignant cells in the subarachnoid space. ${ }^{1,6,15}$ This characteristic pattern is especially found at the base of the brain. 


\section{DIAGNOSTIC PROCEDURES FOR LMM}

Early identification and treatment of LMM may prevent serious neurologic symptoms. ${ }^{13}$ Several diagnostic procedures can be applied to establish the diagnosis.

\section{Cytology of CSF aspirates}

The demonstration of neoplastic cells in CSF by cytologic evaluation is generally regarded as the most important diagnostic criterion for LMM. ${ }^{16}$ Several studies have reported a high specificity of this technique, reporting false positive rates of less than $2 \%$. However, this technique is only moderately sensitive, with $15-20 \%$ of the clinically suspected cases remaining persistently negative even after repeated lumbar punctures. ${ }^{17}$ Furthermore, the cytologic diagnosis in pathologically focal LMM shows a higher percentage of false-negative cases.

The main reasons for these diagnostic problems are: (a) the morphologic resemblance of malignant cells to ependymal cells, (b) the non-malignant aspect of lymphocytes in leptomeningeal localization of non-Hodgkin lymphoma or leukemia, (c) the presence of blood due to traumatic lumbar punctures, and (d) the fact that often only a small number of cells can be evaluated. ${ }^{18,19}$

Because of this low sensitivity of cytologic examination, additional tests are required to establish the diagnosis. On the other hand, the sensitivity of CSF cytology might increase by increasing the number of cells on the slides to be examined. This might be achieved by using coated glass slides, because cells might attach to the slides more firmly.

\section{Biochemical markers}

The diagnostic potential of biochemical tumor markers in the CSF has been studied for $\beta$-glucoronidase, $\beta_{2}$-microglobulin, lactate dehydrogenase (LDH), $\alpha$-fetoprotein ( $\alpha$-FP), carcino-embryonic antigen (CEA), tissue polypeptive antigen (TPp-A), myelin basic protein (MBP), $\beta$-human chorionic gonadotropin ( $\beta$-HCG) and creatine kinase-BB (ck-BB). ${ }^{2,5,20-26}$ Although all of these can be informative to some extent, none of these markers is sensitive enough to improve the cytologic diagnosis of LMM. However, in the case of glucose phosphate isomerase the specificity was found to be high (92\%), suggesting that it can be of diagnostic aid. ${ }^{27}$ Furthermore, CSF sL-selectin (the shed form of L-selectin, an adhesion molecule) as a marker of LMM of sL-selectin positive leukemia demonstrated its usefulness in the detection of meningeal involvement and the monitoring of patients treated for LMM of sL-selectin positive leukemia. ${ }^{28}$

\section{Immunocytochemistry}

Besides the use of biochemical markers to improve the diagnosis of LMM, the usefulness of monoclonal antibodies has been studied. ${ }^{29-35}$ In solid tumor diagnosis, immunocytochemistry seems to be of minor importance, but in the case of leukemia or lymphoma, antibodies against surface markers on lymphocytes can be very useful. Furthermore, cell surface markers can be used to distinguish between reactive and neoplastic lymphocytes by demonstrating monoclonality as a sign of malignancy whenever the cytology of the CSF 
remains unclear. More recently, soluble levels of surface antigens (CD 4 and CD 27) were demonstrated to be very useful immunocytological markers for LMM in lymphoid disease. ${ }^{36,37}$

It can be concluded from the immunocytochemical marker studies that these markers are not useful in case of LMM of solid tumors, but that they can be very informative in cases of LMM of lymphoid malignancies.

\section{Neuro-imaging techniques}

Wasserstrom et $\mathrm{al}^{4}$ studied the role of myelography as a diagnostic adjunct for LMM and demonstrated that its sensitivity was too low (26\%). Other studies ${ }^{13}$ demonstrated a higher sensitivity (27-67\%), but none of these studies established an improvement of the diagnosis of LMM.

Computed tomography (CT) of the central nervous system may be helpful in diagnosing LMM. The most frequently observed abnormality is a sulcal enhancement. Secondly, the finding of a hydrocephalus is very suggestive of LMM. ${ }^{13}$ However, Chamberlain et $\mathrm{al}^{38}$ compared the use of contrast-enhanced CT with that of gadolinium-enhanced magnetic resonance (MR) and concluded that contrast-enhanced CT is unnecessary in patients with suspected LMM because the sensitivity of this diagnostic test is too low. Furthermore, MR was founded to be superior in detecting LMM compared to CT, making it the first diagnostic aid of choice when using neuro-imaging techniques. Other studies have confirmed the usefulness of MR. ${ }^{39-41}$ Freilich et $\mathrm{al}^{42}$ demonstrated that in cases with a typical clinical presentation, abnormal MR-neuro-imaging alone is adequate to establish the diagnosis of LMM.

\section{Neurophysiology}

Electromyography (EMG) and electro-encephalography are of no help in diagnosing LMM, although some studies ${ }^{43,44}$ suggest that EMG can be of help, especially when considering late response studies.

\section{Cell genetic studies}

Since it is thought that malignancy develops due to genetic alterations, cell genetic analysis has been studied to improve the diagnosis of LMM. First, in vivo chromosome analysis of metaphysic cells was reported to be useful. ${ }^{45}$ Subsequently, newer cytogenetic techniques were studied, such as flowcytometry (FCM) and DNA single cell cytometry. ${ }^{46-48}$ Both techniques measure the chromosomal content of cells. DNA single cell cytometry determines the DNA content of chosen cells using a TV-image analysis system combined with an automated microscope. FCM determines the DNA-RNA content by measuring the fluorescence emission of stained DNA and RNA with an argon ion laser at the appropriate wave length. An increased chromosomal content (aneuploidy) measured by these methods can be considered a sign of malignancy. Both techniques give extra diagnostic information, but the sensitivity is too low (69-79\%) to improve the diagnosis of LMM. Furthermore, the 
numbers of cells required (at least 500 cells in the study by Cibas et $\mathrm{al}^{46}$ ) is a disadvantage of the FCM technique.

Amplification of specific genetic alterations using the polymerase-chain reaction (PCR) technique has been studied in cases of leukemia and lymphomas with known genetic alterations. ${ }^{49.50}$ Van Dongen et $\mathrm{al}^{51}$ demonstrated that PCR combined with immunological marker analysis in cases of acute leukemia can be used to detect minimal residue of disease. They were able to detect leukemic cells at a frequency as low as one in 1,000 to 10,000 cells. Rhodes et al ${ }^{52}$ compared PCR with conventional cytology of CSF and concluded that PCR can establish the correct diagnosis when cytology is not conclusive. The main disadvantage of the PCR technique is that the genetic alteration of the neoplastic process must be known, which is often not the case (especially in solid tumors).

In conclusion, recent developments in the diagnostic procedure of LMM have shown some promising markers (both immunological and cytogenetic) for LMM, especially in patients with leukemia or lymphomas. Furthermore, MR-imaging techniques can also be useful in the diagnosis of LMM. Further improvement of the diagnostic accuracy of LMM is however necessary. Therefore, we studied the role of fluorescence in situ hybridization (FISH), a cytogenetic technique that can be used in interphase nuclei in the CSF to detect numerical or structural genetic aberrations as a sign of malignancy to diagnose LMM. Below we explain the principles of the FISH technique.

\section{FLUORESCENCE IN SITU HYBRIDIZATION FOR DETECTION OF GENOMIC ABERRATIONS}

The fluorescence in situ hybridization (FISH) technique, which uses chromosome specific probes, allows the detection of numerical chromosome aberrations in the interphase nucleus, and is generally referred to as "interphase cytogenetics". ${ }^{53}$ The developments in probe labeling techniques, the generation of different types of probes and technical improvements in the processing of biological materials have now reached a point where the FISH technique can be considered a significant adjunct to the more established methods for detection and characterization of genetic aberrations in cancer. ${ }^{54.59}$ The FISH methods have been successfully applied to a variety of cell and tissue preparations, such as single cells isolated from solid cancers, cells isolated from paraffin sections, cells from frozen sections and cytological samples.

Several types of DNA probe can be used to detect numerical and structural chromosome aberrations in cancer cells. DNA probes recognizing tandemly repeated DNA sequences, which are mostly present in the centromeric and telomeric regions, are now routinely applicable in daily practice. The sequences targeted by these probes are typically alpha satellite or satellite III sequences, which are usually repeated a hundred to thousand fold. This results in DNA targets of up to several thousands of kilobase pairs (kbp) localized in the compact centromeric regions of the individual chromosomes. Such repetitive probes have been developed for most of the human chromosomes and many are now commercially 
available (Oncor, Gaithersburg, Maryland, USA; Vysis, Naperville, Illinois, USA; American Type Culture Collection, Rockville, USA; Amersham, Buckingshamshire, UK).

The FISH signal intensity of these probes after hybridization is high and the hybridization signal is tightly localized in metaphase and interphase nuclei. Since the number of signals is constant during the cell cycle, these probes can be scored rapidly and accurately.

Several methods for FISH detection have been described, based on the introduction of a reporter molecule into the DNA probe, which can then be detected immunocytochemically after hybridization to its specific target. Over the last decade about twenty different hapten and fluorochrome labeling procedures have been developed. Two of these, the biotin and digoxigenin labeling procedures, are most frequently used. These haptens are incorporated into the probe by nick translation or random priming, or during a polymerase chain reaction (PCR) using hapten or fluorochrome labeled triphosphates.

In most cases the haptens are detected by standard affinity cytochemical techniques. In the case of e.g. biotin, the reporter molecule can be detected with labeled (strept)avidin molecules or monoclonal antibiotin followed by incubation with labeled secondary antibodies. Labels can be fluorochromes, like fluorescein (FITC), rhodamine (TRITC) and amino-methyl-coumarin-acetic acid (AMCA), or enzymes such as peroxidase and alkaline phosphatase. In the case of directly fluorochrome labeled DNA probes no immunological detection is needed, although an immunological amplification step to obtain a higher signal intensity, using anti-fluorochrome antibodies and secondary antibodies, is possible.

To allow hybridization of the probe to its target sequences in the cell preparation the sample is fixed and permeabilized. Standard tissue fixatives, such as $4 \%$ formaldehyde in phosphate-buffered saline (PBS), methanol/acetic acid (3/1), 70\% ethanol, methanol/aceton or carbowax/ethanol, which is normally used for cytological analysis, are fully compatible with the FISH procedure. Depending on the amount of cytoplasm, or the crosslinking of nuclear proteins, a proteolytic pretreatment is needed to permeabilize the cell for macromolecular reagents such as DNA probes and antibodies, thus allowing FISH of the probe. Also, digestion reduces background as a result of autofluorescence, leading to maximum signal to noise ratios.

During this permeabilization step, however, isolated cells or parts of tissue sections may be lost, in particular when they are attached to non-coated glass slides. This can be avoided by coating the slides using either poly-L-lysine, gelatin chrome-alum or aminoalkyl silane. Modified probes are hybridized under standard conditions. Protocols have been developed to denaturate target DNA and probe DNA simultaneously or separately. After hybridization, in most cases overnight, washing procedures are used to remove aspecifically bound probe.

After these washing steps, hybridized probes are detected immunohistochemically. The fluorescent ISH signals are evaluated by counting spots in a few hundred to several thousand nuclei. It is assumed that the chromosome copy number is identical to the number of hybridization signals obtained with its specific centromeric probe. The following criteria are applied for a proper evaluation with minimal inter- and intraobserver variation:

a) overlapping nuclei are not counted; b) only nuclei in which the FISH signals have more or less the same homogeneous fluorescence intensity are evaluated, unless indications of a 
partial deletion or polymorphism exist; c) minor hybridization signals, which can be recognized by a lower intensity and smaller spot area are not counted; d) fluorescent spots or patches of fluorescence in nuclei are only included if the signals are completely separated.

\section{REFERENCES}

1. Olson ME, Chernik NL, Posner JB. Infiltration of the leptomeninges by systemic cancer. A clinical and pathologic study. Arch Neurol 1974;30:122-137.

2. Posner JB: Neurologic complications of cancer. Philadelphia: FA Davis Comp, 1995:143-171.

3. Little JR, Dale AJ, Okazaki H. Meningeal carcinomatosis. Clinical manifestations. Arch Neurol 1974;30:138-143.

4. Wasserstrom WR, Glass JP, Posner JB. Diagnosis and treatment of leptomeningeal metastases from solid tumors: experience with 90 patients. Cancer 1982;49:759-772.

5. Chamberlain MC. New approaches to and current treatment of leptomeningeal metastases. Curr Opin Neurol 1994;7:492-500.

6. Kokkoris CP. Leptomeningeal carcinomatosis. How does cancer reach the pia-arachnoid? Cancer 1983;51:154-160.

7. Price RA, Johnson WW. The central nervous system in childhood leukemia: I. The arachnoid. Cancer 1973;31:520-533.

8. Azzarelli B, Mirkin D, Goheen M, Muller J, Crockett C. The leptomeningeal vein. A site of re-entry of leukemic cells into the systemic circulation. Cancer 1984;54:1333-1343.

9. Russel DS, Rubinstein LJ. Pathology of tumours of the nervous system. $4^{\text {th }}$ ed. Baltimore: Williams and Wilkins, 1977:214-215.

10. Twijnstra A, Glass JP. Leptomeningeal metastasis from solid extracranial tumors. In: Twijnstra A, Keyser A, Ongerboer de Visser BW, eds. Neuro-oncology. Amsterdam: Elsevier Science Publ B.V., 1993:257-265.

11. Balm M, Hammack J. Leptomeningeal carcinomatosis. Presenting features and prognostic factors. Arch Neurol 1996;53:626-632.

12. Ingram LC, Fairclough DL, Furman WL, et al. Cranial nerve palsy in childhood acute lymphoblastic leukemia and non-Hodgkin's lymphoma. Cancer 1991;67:2262-2268.

13. Hiesiger EM, Picco-Del Bo A, Lipschutz LE, et al. Experimental meningeal carcinomatosis selectively depresses local cerebral glucose utilization in rat brain. Neurology 1989;39:90-95.

14. Latchaw RE, Gabrielsen TO, Seeger JF. Cerebral angiography in meningeal sarcomatosis and carcinomatosis. Neuroradiology 1974;8:131-139.

15. Gonzalez-Vitale JG, Garcia-Bunuel R. Meningeal carcinomatosis. Cancer 1976;37:29062911.

16. Glass JP, Melamed M, Chernik NL, Posner JB. Malignant cells in cerebrospinal fluid (CSF): the meaning of a positive CSF cytology. Neurology 1979;29:1369-1375.

17. Bigner SH, Johnston WW. The cytopathology of cerebrospinal fluid. II. Metastatic cancer, meningeal carcinomatosis and primary central nervous system neoplasms.

Acta Cytol 1981;25:461-480.

18. Van Heerde P. Cytology of cerebrospinal fluid. In: Twijnstra A, Keyser A, Ongerboer de Visser BW, eds. Neuro-oncology. Amsterdam: Elsevier Science Publ B.V., 1993:266-271.

19. Bigner SH. Central nervous system. In: Bibbo M, ed. Comprehensive Cytopathology. Philadelphia: WB Saunders Comp, 1991:468-483. 
20. Twijnstra A. Cerebrospinal fluid biochemical markers in central nervous system metastasis: clinical applications. Thesis. University of Maastricht, The Netherlands, 1986.

21. Twijnstra A, Van Zanten AP. Biochemical markers in cerebrospinal fluid. In: Twijnstra A, Keyser A, Ongerboer de Visser BW, eds. Neuro-oncology. Amsterdam: Elsevier Science Publ B.V., 1993:272-274.

22. Klee G, Tallman R, Goellner J, Yanagihara T. Elevation of carcinoembryonic antigen in cerebrospinal fluid among patients with meningeal carcinomatosis.

Mayo Clin Proc 1986;6: 9-13.

23. Ernerudh J, Olsson T, Berlin G, Von Schenck H. Cerebrospinal fluid immunoglobulins and $\beta_{2}$-microglobulin in lymphoproliferative and other neoplastic diseases of the central nervous system. Arch Neurol 1987;44:915-920.

24. Bach F, Soletormos G, Dombernowsky P. Tissue polypeptide antigen activity in cerebrospinal fluid: a marker of central nervous system metastases of breast cancer. J Natl Cancer Inst 1991;83:779-784.

25. Nakagawa H, Yamada M, Kanayama T, et al. Myelin basic protein in the cerebrospinal fluid of patients with brain tumors. Neurosurg 1994;34:825-833.

26. Bach F, Bjerregaard B, Soletormos G, Bach FW, Horn T. Diagnostic value of cerebrospinal fluid cytology in comparison with tumor marker activity in central nervous system metastases secondary to breast cancer. Cancer 1993;72:2376-2382.

27. Newton HB, Fleisher M, Schwartz MK, Malkin MG. Glucosephosphate isomerase as a CSF marker for leptomeningeal metastasis. Neurology 1991;41: 395-398.

28. Stucki A, Cordeg A-S, Monai N, De Flangergues J-C, Shapira M, Spertini O. Cleaved L-selectin concentrations in meningeal leukaemia. Lancet 1995;345: 286-289.

29. Hancock WW, Medley G. Monoclonal antibodies to identify tumour cells in CSF. Lancet 1983;2 (8352):739-740.

30. Coakham HB, Garson JA, Brownell B, et al. Use of monoclonal antibody panel to identify malignant cells in cerebrospinal fluid. Lancet 1984;1 (8386):1095-1098.

31. Garson JA, Coakham HB, Kemshead JT, et al. The role of monoclonal antibodies in brain tumour diagnosis and cerebrospinal fluid (CSF) cytology. J Neurooncol 1985;3:165-171.

32. Boogerd W, Vroom ThM, Van Heerde P, Brutel de la Rivière G, Peterse JL, Van der Sande JJ. CSF cytology versus immunocytochemistry in meningeal carcinomatosis.

JNNP 1988;51:142-145.

33. Ezrin-Waters C, Klein M, Deck J, Lang AE. Diagnostic importance of immunological markers in lymphoma involving the central nervous system. Ann Neurol 1984;6:668-672.

34. Tani E, Costa I, Svedmyr E, Skoog L. Diagnosis of lymphoma, leukemia and metastatic tumor involvement of the cerebrospinal fluid by cytology and immunocytochemistry.

Diagn Cytopathol 1995;12:14-22.

35. Ernerudh J, Olsson T, Berlin G, Gustafson B. Karlsson H. Cell surface markers for diagnosis of central nervous system involvement in lymphoproliferative diseases.

Ann Neurol 1986;20:610-615.

36. Uozumi K, Hanada S, Ishitsuka K, et al. Elevated soluble CD4 levels in the cerebrospinal fluid in patients with adult T-cell leukemia. Am J Hematology 1994;46:95-100.

37. Kersten MJ, Evers LM, Dellemijn PLI, et al. Elevation of cerebrospinal fluid soluble CD27 levels in patients with meningeal localization of lymphoid malignancies.

Blood 1996;87:1985-1989. 
38. Chamberlain MC, Sandy AD, Press GA. Leptomeningeal metastasis: a comparison of gadolineum-enhanced MR and contrast-enhanced CT of the brain.

Neurology 1990;40:435-438.

39. Krol G, Sze G, Malkin M, Walker R. MR of cranial and spinal meningeal carcinomatosis: comparison with CT and myelography. AJR 1988;151:583-588.

40. Sze G, Soletsky S, Bronen R, Krol G. MR Imaging of the cranial meninges with emphasis on contrast enhancement and meningeal carcinomatosis. AJNR 1989;10:965-975.

41. Yousem DM, Patrone PM, Grossman RI. Leptomeningeal metastases: MR Evaluation. J Comput Assist Tomogr 1990;14:255-261.

42. Freilich RJ, Krol G, DeAngelis LM. Neuroimaging and cerebrospinal fluid cytology in the diagnosis of leptomeningeal metastasis. Ann Neurol 1995;38:51-57.

43. Argor Z, Siegal T. Leptomeningeal metastases: Peripheral nerve and root involvement; clinical and electrophysiological study. Ann Neurol 1985;17:593-596.

44. Kaplan JG, Portenoy RK, Pack DR, DeSouza T. Polyradiculopathy in leptomeningeal metastases: the role of EMG and late response studies. J Neurooncol 1990;9:219-224.

45. Granberg-Öhman IF, Andersson BI, Gupta SK, Lying-Tunell UM. Chromosome analysis in meningeal carcinomatosis. Acta Neurol Scandinav 1979;60:255-259.

46. Cibas ES, Malkin MG, Posner JB, Melamed MR. Detection of DNA abnormalities by flow cytometry in cells from cerebrospinal fluid. Am J Clin Pathol 1987;88:570-577.

47. Dux R, Kindler-Röhrborn A, Annas M, Faustmann P, Lennartz K, Zimmerman CW. A standardized protocol for flow cytometric analysis of cells isolated from cerebrospinal fluid. J Neurol Sci 1994;121:74-78.

48. Biesterfeld S, Bernhard B, Bamborschke S, Böcking A. DNA single cell cytometry in lymphocytic pleocytosis of the cerebrospinal fluid. Acta Neuropathol 1993;86:428-434.

49. Stetler-Stevenson M, Raffeld M, Cohen P, Cossman J. Detection of occult follicular lymphoma by specific DNA amplification. Blood 1988;72:1822-1825.

50. Shibata D, Nichols P, Sherrod A, Rabinowitz A, Bernstein-Singer L, Hu E. Detection of occult CNS involvement of follicular small cleaved lymphoma by the polymerase chain reaction. Mod Path 1990;3:71-75.

51. Van Dongen JJM, Breit TM, Adriaansen HJ, Beishuizen A, Hooykaas H. Detection of minimal residual disease in acute leukemia by immunological marker analysis and polymerase chain reaction. Leukemia 1992;6:47-59.

52. Rhodes $\mathrm{CH}$, Glantz MJ, Glantz L, et al. A comparison of polymerase chain reaction examination of cerebrospinal fluid and conventional cytology in the diagnosis of lymphomatous meningitis. Cancer 1996;77:543-548.

53. Cremer T, Landegent J, Bruckner A, et al. Detection of chromosome aberrations in the human interphase nucleus by visualization of specific target DNAs with radioactive and non-radioactive in situ hybridization techniques diagnosis of trisomy 18 with probe L1.84. Hum Genet 1986;74:346-352.

54. Tkachuk DC, Pinkel D, Kuo W-L, Weier H-U, Gray J. Clinical applications of fluorescence in situ hybridization. Genet Anal Techn Appl 1991;8: 67-74.

55. Bentz M, Döhner H, Cabot G, Lichter P. Fluorescence in situ hybridization in leukemias: "The FISH are Spawning". Leukemia 1994;8:1447-1452.

56. Poddighe PJ, Ramaekers FCS, Hopman AHN. Interphase cytogenetics of tumors. J Pathol 1992;166:215-224. 
57. Hopman AHN, Voorter CEM, Ramaekers FCS. Detection of genomic changes in cancer by in situ hybridization. Mol Biol Rep 1994;19:31-44.

58. Lichter P, Boyle AL, Cremer C, Ward DC. Analysis of genes and chromosomes by non-isotopic in situ hybridization. Genet Anal Techn Appl 1991; 8:24-35.

59. Speel EJM, Ramaekers FCS, Hopman AHN. Cytochemical detection systems for in situ hybridization, and the combination with immunocytochemistry "Who is still afraid of Red, Green and Blue?" Histochem J 1995;27:833-858. 


\section{CHAPTER 2}

\section{LEPTOMENINGEAL METASTASES IN PATIENTS WITH}

SOLID AND HEMATOLOGIC MALIGNANCIES.

Presenting features and value of diagnostic procedures

Presented at the $51^{\text {st }}$ annual meeting of the American Academy of Neurology, 21-04-1999, Toronto, Canada.

Adapted from:

$\mathrm{RJ}$ van Oostenbrugge and A Twijnstra.

Presenting features and value of diagnostic procedures in leptomeningeal metastases.

Neurology (in press). 


\section{ABSTRACT}

Leptomeningeal metastases (LMM) must be considered in any cancer patient presenting with neurologic symptoms or signs. Although CSF cytology is only moderately sensitive, it is the primary diagnostic test. Presenting neurologic features and results of routine diagnostic tests can improve the diagnostic assessment. We studied the presenting features and the value of routine diagnostic procedures in relation to the histology of the primary malignant disease in 45 patients with LMM of solid $(n=30)$ or hematologic $(n=15)$ malignancies in order to improve the diagnostic assessment.

Patients with solid LMM mostly presented with spinal or radicular symptoms (53\%), whereas patients with hematologic LMM more often showed cranial nerve dysfunction at presentation (53\%). Multifocal neurologic symptoms were seen in $67 \%$ of the patients. The first CSF cytology demonstrated malignant cells more frequently in solid LMM compared to hematologic LMM (73\% and 53\%, respectively). Extra lumbar punctures increased the sensitivity of cytology to a greater extent in hematologic LMM than in solid LMM (34\% and 10\%, resp.). Abnormal neuro-imaging findings were found in $58 \%$ of the patients. Comparing both groups, more abnormal results were found in solid LMM than in hematologic LMM (67\% and 40\%, resp.). Increased total CSF protein in combination with either multifocal neurologic symptoms or abnormal neuro-imaging findings was found in $73 \%$ of the patients with a negative first CSF cytologic examination.

In conclusion, patients with LMM presented differently depending on the histology of the primary tumor, although many of the patients presented with multifocal neurologic symptoms.

In case of a negative first CSF cytologic examination, multiple lumbar punctures increased the diagnostic accuracy especially in hematologic LMM. LMM could also be diagnosed if total CSF protein was increased in the presence of multifocal neurologic symptoms or abnormal neuro-imaging findings in a patient with known cancer. 


\section{INTRODUCTION}

Leptomeningeal metastases (LMM) arise in approximately $8 \%$ of patients with systemic cancer. Although almost any type of malignant disease can disseminate to the leptomeninges, this is mostly found in patients with high-malignant hematologic diseases and in solid tumors

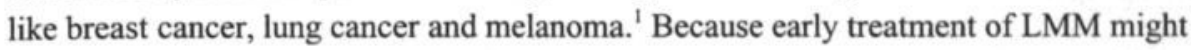
prevent neurologic deterioration, it is important to diagnose LMM as early as possible. The detection of malignant cells by cytologic evaluation of cerebrospinal fluid (CSF) is generally required for a definitive diagnosis. ${ }^{2}$ However, cytodiagnosis of CSF is only moderately sensitive and the use of clinical presenting features and the results of other diagnostic procedures to establish the diagnosis has been suggested. ${ }^{3}$

The aim of the present study was to compare the presenting features and value of some routine diagnostic procedures in patients with LMM of solid tumors and hematologic malignancies in order to improve the diagnostic assessment of these patients.

\section{PATIENTS AND METHODS}

From January 1995 to December 1997, all consecutive adult patients (age > 15 years) seen at the department of Neurology of the University Hospital of Maastricht with LMM secondary to a solid or hematologic malignancy were included. The following demographic features were collected for both groups: age at presentation, sex, primary tumor, extent of systemic disease, and time interval between the diagnosis of the primary tumor and the diagnosis of LMM.

Furthermore, we collected the following clinical data: presenting neurologic symptoms and signs classified for the level of the neuraxis involved, time interval between neurologic symptoms and the final diagnosis of LMM, CSF cytology, level of protein and glucose in the CSF, CSF cell count and results of imaging studies. In cases with negative CSF cytology the additional diagnostic value of other diagnostic procedures was determined.

The results found in both groups were compared and the chi-square test was used for the assessment of significant differences.

\section{RESULTS}

We included 30 patients with solid LMM and 15 with hematologic LMM in this study. Patient characteristics and histologic data of the primary tumor are shown in table 1. Breast and lung cancer were responsible for the majority of LMM (73\%) in the patients with solid LMM, whereas acute lymphoblastic leukemia (ALL) and high-grade non-Hodgkin lymphoma (NHL) accounted for all the cases with hematologic LMM. The primary tumor showed evidence of active disease in all except one patient in both groups. 
Table 1: Patients characteristics and histology of the primary tumor in 45 patients with leptomeningeal metastases due to a solid or hematologic malignancy.

\begin{tabular}{|c|c|c|c|}
\hline Solid tumors & & Hematologic malignancies & \\
\hline Sex & & Sex & \\
\hline female 20 & & female 5 & \\
\hline male 10 & & male 10 & \\
\hline & & Age & \\
\hline $19-78$ years (mean: 53 & & 16 - 67 years (mean: 50 ) & \\
\hline Histology & & Histology & \\
\hline Breast cancer & 11 & High grade non-Hodgkin lymphoma & 10 \\
\hline Lung cancer & 11 & Acute lymphoblastic leukemia & 5 \\
\hline - SCLC & & & \\
\hline - NSCLC 6 & & & \\
\hline Unknown primary & 2 & & \\
\hline Renal cell carcinoma & 1 & & \\
\hline Colon carcinoma & 1 & & \\
\hline Bladder carcinoma & 1 & & \\
\hline Medulloblastoma & 1 & & \\
\hline Pancreas carcinoma & 1 & & \\
\hline Dysgerminoma & 1 & & \\
\hline
\end{tabular}

Abbreviations: SCLC: small-cell lung cancer, NSCLC: non-small-cell lung cancer.

The time interval between the primary tumor and the diagnosis of LMM was longer in the patients with solid LMM ( 0 - 126 months; mean: 26$)$ compared to patients with hematologic LMM ( 0 - 47 months; mean 10). LMM was diagnosed more often as the first manifestation of cancer in patients with hematologic malignant disease $(n=2 ; 14 \%)$ than in those with a solid tumor $(\mathrm{n}=2 ; 7 \%)$. Furthermore, LMM was diagnosed simultaneously in two patients with hematologic disease, so four out of 15 patients (27\%) with hematologic LMM were diagnosed at the beginning of the malignant disease.

Frequencies of the presenting symptoms and signs in relation to the level of the neuraxis are shown in table 2. Symptoms and signs of cranial nerve dysfunction were significantly more common in patients with hematologic LMM, while patients with solid LMM presented more often with cerebral and/or spinal symptoms and signs. Multifocal neurologic symptoms and/or signs were present in 30 patients $(67 \%)$, with almost equal occurrence in both types of malignancy ( $73 \%$ versus $63 \%$ ).

The time interval between the neurologic symptoms and signs and the final diagnosis ranged from 0 to 40 weeks (mean 7 weeks; median 4 weeks) in patients with solid LMM and from 0 to 45 weeks (mean 5 weeks; median 1 week) in patients with hematologic LMM.

Patients with a diagnostic delay of more than 4 weeks were found significantly more often in the solid LMM group compared to the hematologic LMM group ( $60 \%$ versus $27 \%$; $p<0.05$ ). These patients presented mainly with unifocal symptoms without neurologic signs. 
Table 2: Neurologic symptoms and signs at diagnosis in 45 patients with LMM, according to type of primary malignancy.

\begin{tabular}{|lccccccc|}
\hline & Total & Solid & Hematologic & P-value \\
\hline & symptoms / signs & symptoms / signs & symptoms / signs & \\
\hline Cerebral & $15 / 16$ & $13 / 13$ & $2 / 3$ & 0.044 \\
\hline Cranial nerves & $14 / 20$ & $6 / 10$ & $8 / 10$ & 0.023 \\
\hline Spinal and radicular & $21 / 19$ & $16 / 15$ & $5 / 4$ & 0.205 \\
\hline Multifocal symptoms & $30 / 26$ & $19 / 18$ & $11 / 8$ & 0.314 \\
\hline None & $1 / 6$ & $-/ 6$ & $1 / / 1$ & - \\
\hline
\end{tabular}

Table 3 shows the numbers and percentages of abnormal results for the levels of CSF protein and glucose, CSF cell count, radiographic tests, and first CSF cytology.

The CSF protein level was raised $(>0.5 \mathrm{~g} / \mathrm{l})$ in 34 patients $(76 \%)$. Decreased CSF glucose $(<2.5 \mathrm{mmol} / \mathrm{l})$ was found in 13 patients $(29 \%)$. No difference was found between the two groups as regards the percentages of patients with abnormal CSF protein or glucose. In both groups, a decreased CSF glucose with normal CSF protein was observed only once.

The combination of multifocal neurology and raised CSF protein was found in 19 patients $(42 \%)$. Patients with hematologic LMM showed this combination more often than patients with solid $\mathrm{LMM}, 53 \%$ and $37 \%$ respectively $(\mathrm{p}>0.05)$.

Table 3: Numbers and percentages of abnormal results of CSF protein and glucose, cell count, radiographic tests and first CSF cytology in 45 patients with LMM, according to type of primary malignancy.

\begin{tabular}{|lrrrc|}
\hline & Total(n=45) & Solid(n=30) & Hematologic(n=15) & P-value \\
\hline Increased total protein & $34(76 \%)$ & $23(77 \%)$ & $11(73 \%)$ & 0.902 \\
\hline Decreased glucose & $13(29 \%)$ & $9(20 \%)$ & $4(27 \%)$ & 0.908 \\
\hline Raised cell count & $15(33 \%)$ & $13(57 \%)$ & $2(25 \%)$ & 0.057 \\
\hline Abnormal radiology & $26(58 \%)$ & $20(67 \%)$ & $6(40 \%)$ & 0.088 \\
\hline - CT & $12 / 38(32 \%)$ & $10 / 24(42 \%)$ & $2 / 14(14 \%)$ & 0.165 \\
\hline - MRI & $18 / 32(56 \%)$ & $13 / 22(59 \%)$ & $5 / 10(50 \%)$ & 0.924 \\
\hline Positive first cytology & $30(67 \%)$ & $22(73 \%)$ & $8(53 \%)$ & 0.314 \\
\hline
\end{tabular}


The cell count was raised in 15 patients (33\%). This was seen more frequently in patients with solid LMM (57\%) compared to patients with hematologic LMM (25\%).

The results of the radiographic tests (computer tomography (CT) and/or magnetic resonance imaging (MRI)) of the central nervous system (CNS) were abnormal in $58 \%$ of all cases. Comparing both groups, more abnormal results were found in patients with solid LMM than in those with hematologic LMM (67\% versus $40 \%, \mathrm{p}>0.05)$. In total, CT scanning was less sensitive than MRI ( $32 \%$ versus $56 \%, \mathrm{p}>0.05)$, especially in patients with hematologic LMM.

Malignant cells were detected in $67 \%$ of all patients at first cytologic examination of the CSF. Additional cytologic examinations after repeated lumbar punctures classified eight more cases as malignant (three solid LMM and five hematologic LMM), increasing the sensitivity of cytology to $84 \%$. Repeated cytology was more useful in patients with hematologic LMM, increasing the sensitivity by $34 \%$, whereas in solid LMM it increased by $10 \%$. CSF cytology remained persistently negative in $16 \%$ of the patients, without a difference between the two groups.

In the 15 cases with negative first CSF cytology, raised CSF protein, raised cell count, multifocal neurology, or abnormal radiographic tests were found in, respectively, $12(80 \%)$, $6(40 \%), 10(67 \%)$, and $6(40 \%)$ of the patients. Three patients had only one abnormal test result (one multifocal neurology, one raised CSF protein, and one abnormal radiographic test).

Eleven patients had raised CSF protein combined with either an abnormal radiographic test $(n=5)$ or multifocal neurology $(n=9)$ or both $(n=3)$. A raised cell count with negative first cytology was always found in combination with increased CSF protein and multifocal symptoms. Only one patient showed no abnormalities in any of the routine diagnostic procedures.

\section{DISCUSSION}

Every patient known with cancer and presenting with neurologic symptoms or signs must be suspected of LMM, although the literature reports that some malignancies are more likely to give rise to LMM than others. ${ }^{1,4-6}$ Our series also showed the same distribution between solid and hematologic malignancies in LMM as that reported by Olson et al. ${ }^{6}$ As expected, solid LMM were found more frequently than hematologic LMM, due to the higher incidence of solid tumors.

LMM may arise at any moment during the course of disease. Nine percent of the patients presented with LMM as the first manifestation of cancer, although this was seen especially in patients with high-grade hematologic tumors. Conversely, LMM developed in $29 \%$ of the patients after a long disease free period. This was mostly seen in patients with solid tumors. In one patient a metachronous appearance of LMM was found after a disease free period of 126 months. This has been reported before and stresses the possibility of LMM in a patient with cancer even after a long disease free period. ${ }^{7}$ 
In general, symptoms and signs of LMM are categorized in three domains of the neuraxis: (1) cerebral hemispheres, (2) cranial nerves, and (3) spinal cord and nerve roots. ${ }^{8}$ In our study, the mode of presentation differed markedly between the two types of LMM. Patients with hematologic LMM presented more often with cranial nerve dysfunction, whereas patients with solid LMM more often had cerebral and radicular symptoms. This finding contrasts with the results found by Kaplan et al, who found cranial nerve dysfunction to be the most frequent presenting sign in both types of LMM. ${ }^{5}$ However, Jayson and Howell found spinal and radicular symptoms and signs to be the most common presenting features in patients with solid LMM. ${ }^{9}$ Furthermore, the difference in clinical presentation supports the assumed different route of dissemination of malignant cells in these two tumor types.

Price and Johnson demonstrated a hematogenous spread of leukemic cells to the leptomeninges, preferably those at the base of the brain. ${ }^{10}$ By contrast, Kokkoris demonstrated that LMM of solid tumors are the result of spreading to the meninges from adjacent tissue metastases, which were mainly vertebral metastases."

Multiple level involvement was present in $67 \%$ of our patients, indicating its status as a hallmark of LMM, as has been reported before. ${ }^{4,6,12}$ Balm et al found multiple level involvement to be less common than single level involvement, which was explained by a heightened clinical suspicion. ${ }^{13}$ We could not confirm this finding in our series of patients. However, we found a longer time interval between presentation and diagnosis in patients with single level involvement, what supports the statement of Balm et al that the clinical suspicion in these patients is low.

Glass et al demonstrated the moderate sensitivity of cytology. ${ }^{14}$ Also, Olson et al and Wasserstrom et al found a high percentage of false-negative cytologic examinations..$^{6,15}$ In more recent studies, however, this percentage was much lower and comparable to our results. ${ }^{5,13,16}$ Although multiple lumbar punctures increase the percentage of positive cytology, ${ }^{6,14}$ we observed this especially in hematologic LMM. The higher percentage of positive results at the first cytology in solid LMM is probably due to the higher number of cells in the CSF samples of these patients. Cytology remained persistently negative in $16 \%$ of our patients in both tumor groups, which was comparable with findings from the literature. ${ }^{17}$ The neuro-imaging results demonstrate the superiority of MRI over CT. Comparing both types of LMM, Freilich et al also found more abnormal radiographic results in patients with solid LMM. ${ }^{16}$ This is probably due to the extent of dissemination of solid tumors to the leptomeninges which frequently causes bulky leptomeningeal infiltration.

Total CSF protein was often found to be increased in the present study. Although not specific, it might be a valuable finding in patients with a negative first CSF cytologic examination for we found total CSF protein to be elevated in $80 \%$ of these patients.

In combination with either multifocal neurologic symptoms or an abnormal radiodiagnostic test, it was possible to diagnose LMM in 11 of the 15 patients $(73 \%)$ with a negative first CSF cytology.

An increased cell count had no additional value. 
In conclusion, we found differences in the presenting features of solid and hematologic LMM. Patients with solid LMM presented most frequently with spinal and radicular symptoms, whereas cranial nerve dysfunction was mostly present in hematologic LMM. Although multifocal neurologic symptoms are a hallmark of LMM, many patients presented with single level involvement. In cases with a negative first cytologic CSF examination, multiple lumbar punctures are useful, especially in patients with hematologic malignancies. We also demonstrated that LMM can be diagnosed in a patient with known cancer whenever the total CSF protein is increased in combination with multifocal neurologic symptoms or abnormal neuro-imaging findings, preferably by MRI.

\section{REFERENCES}

1. Posner JB, Chernik NL. Intracranial metastases from systemic cancer. Adv Neurol 1978;19:579-592.

2. Chamberlain MC. Leptomeningeal metastases. In: Vecht Ch J, ed. Handbook of Clinical Neurology, Vol. 25 (69): Neuro-Oncology, Part III. Amsterdam: Elsevier Science B.V., 1997:151-165.

3. DeAngelis LM. Current diagnosis and treatment of leptomeningeal metastasis. J Neurooncol 1998;38:245-252.

4. Bleyer WA, Byrne TN. Leptomeningeal cancer in leukemia and solid tumors. Curr Probl Cancer 1988;12:181-238.

5. Kaplan JG, DeSouza TG, Farkash A, et al. Leptomeningeal metastases: comparison of clinical features and laboratory data of solid tumors, lymphomas and leukemias. J Neurooncol 1990;9:225-229.

6. Olson ME, Chernik NL, Posner JB. Infiltration of the leptomeninges by systemic cancer. A clinical and pathologic study. Arch Neurol 1974;30:122-137.

7. Coslett HB, Teja K, Sutula TP. Meningeal carcinomatosis 21 years following bronchioloalveolar carcinoma: diagnosis by cisternal CSF examination. Cancer 1982;49:173-176.

8. Chamberlain MC. New approaches to and current treatment of leptomeningeal metastases. Curr Opin Neurol 1994;7:492-500.

9. Jayson GC, Howell A. Carcinomatous meningitis in solid tumours. Ann Oncol 1996;7:773-786.

10. Price RA, Johnson WW. The central nervous system in childhood leukemia:I. The arachnoid. Cancer 1973;31:520-533.

11. Kokkoris CP. Leptomeningeal carcinomatosis. How does cancer reach the pia-arachnoid? Cancer 1983;51:154-160.

12. Posner JB. Neurologic complications of cancer. Philadelphia: FA Davis Comp, 1995:143-171.

13. Balm M, Hammack J. Leptomeningeal carcinomatosis. Presenting features and prognostic factors. Arch Neurol 1996;53:626-632.

14. Glass JP, Melamed M, Chernik NL, Posner JB. Malignant cells in cerebrospinal fluid (CSF): The meaning of a positive CSF cytology. Neurology 1979;29:1369-1375.

15. Wasserstrom WR, Glass JP, Posner JB. Diagnosis and treatment of leptomeningeal metastases from solid tumors: experience with 90 patients. Cancer 1982;49:759-772.

16. Freilich RJ, Krol G, DeAngelis LM. Neuroimaging and cerebrospinal fluid cytology in the diagnosis of leptomeningeal metastasis. Ann Neurol 1995;38:51-57. 
17. Bigner SH, Johnston WW. The cytopathology of cerebrospinal fluid.II. Metastatic cancer, meningeal carcinomatosis and primary central nervous system neoplasms. Acta Cytol $1981 ; 25: 461-480$. 



\section{CHAPTER 3}

THE USE OF POLY-L-LYSINE COATED SLIDES FOR CYTOSPINNING OF CEREBROSPINAL FLUID (CSF) INCREASES THE NUMBER OF CELLS WITHOUT IMPROVEMENT OF THE SENSITIVITY OF CSF CYTOLOGY

Adapted from:

RJ van Oostenbrugge, JW Arends, R Buchholtz and A Twijnstra.

Cytology of cerebrospinal fluid. Are polylysine-coated slides useful? Acta Cytologica 1997;41:1510-1512. 


\section{ABSTRACT}

We studied the effect of using poly-L-lysine coated (PLC) slides for cytospinning on morphology and number of cells in cerebrospinal fluid (CSF) obtained from 50 patients by lumbar punctures and its usefulness in improving the diagnostic sensitivity of the cytological examination of CSF.

After centrifugation of the aliquots, $400 \mu \mathrm{L}$ were used for cytospins on PLC and plain glass slides. After Giemsa staining, random area cell counts were made for a total of 100 microscopic fields (using the X40 objective) and cytomorphology was assessed.

We found no difference in cytomorphological quality between PLC and plain glass slides. The total number of cells was higher on the PLC slides $(30,674$ vs. 28,426 ; mean value per slide 614 vs. 569), with ranges of $0-11,076$ (median value 38 ) and $0-10,980$ (median value 24) respectively. This difference was significant (Wilcoxon Matched-Pairs Signed-Rank test, $\mathrm{p}<0.05$ ). The higher number of cells influenced the diagnostic assessment in one case, in which only the PLC slide was conclusive.

In conclusion, a significantly higher number of cells were found when PLC slides were used in cytopathological assessment of CSF samples resulting, however, in only minor improvement of the diagnostic sensitivity. 


\section{INTRODUCTION}

Leptomeningeal metastases (LMM) are characterized by diffuse or multifocal infiltration of the leptomeninges by neoplastic cells and is a well recognized complication of carcinomas, hematologic malignancies, and primary tumors of the central nervous system. ${ }^{1,2,3}$ Apart from surgical biopsy cytological examination of the cerebrospinal fluid (CSF) to detect malignant cells is the most reliable method to detect LMM during life. ${ }^{1,2,45}$ However, cytological methods applied to CSF are frequently unsatisfactory, with false-negative results due to difficulties in sampling, the preparation of the cytological slides, and the low number of cells in the specimen. $5.6,7,8$

Cytocentrifugation of CSF is a well established method resulting in good cell morphology, but with considerable cell loss. ${ }^{5,9}$ To increase the number of cells, some authors advocate frosted glass slides ${ }^{10}$ or the use of a coating on the surface of the slides ${ }^{11,12}$ to allow the cells to become attached more firmly. An inquiry in the Netherlands among twenty referral centers for cytopathology showed that only two laboratories used coated slides (organocylane and albumin) during cytospinning of CSF.

We studied the use of a poly-L-lysine coating during the cytospinning technique to determine whether the number of cells in CSF could be increased without loss of morphological features.

\section{MATERIAL AND METHODS}

Fifty specimens of CSF were obtained by lumbar puncture. After centrifugation (Hettich Rotanta; model 3500 ) of $8 \mathrm{~mL}$ at 2,000 rpm for 10 minutes, the supernatant was removed and $400 \mu \mathrm{L}$ of the sediment were used to prepare cytospins (at $700 \mathrm{rpm}$ for 10 minutes (Miles Cyto-Tek)) on PLC slides and plain glass slides. After Giemsa staining, random area cell counts were performed using the X40 objective for a total of 100 fields. Red blood cells were not counted because these do not influence the diagnostic process. Two persons (RvO/RB) assessed the morphology of cells attached to the both slides to determine whether this was influenced by the use of a coating. Finally, different cytopathologists reviewed the two slides of each sample to determine a possible influence of the poly-L-lysine coating on the diagnostic interpretation.

The PLC slides were prepared in the following way: poly-L-lysine was diluted $(0.1 \%)$ with distilled water, and this solution was applied to the glass slide surface with a Pasteur pipette and left to dry at room temperature. The coated slides were stored at $4^{\circ} \mathrm{C}$.

For statistical analysis the Wilcoxon Matched-Pairs Signed-Rank test was used to determine whether differences found between the two types of slides were significant. 


\section{RESULTS}

We found no differences in cytomorphology between the two types of slides.

Table 1 shows the total numbers of cells, with the mean value and the range in the number of cells with median value for the two slides. It was clear that the PLC slides showed higher total numbers of cells, and that the median value of the range was also higher. These differences were significant $(2$-tailed $\mathrm{p}<0.05)$. However, if only differences of $10 \%$ or more were considered to be relevant, no significant difference could be found. Although the numbers of cells on the coated slides were significantly higher, this changed the diagnostic assessment in only one case, in which the PLC slide provided the diagnosis. It concerned a case of LMM due to an unknown primary tumor.

Table 1: Total numbers, mean values, ranges and median values of cells attached to the two types of slides.

\begin{tabular}{|lcccc|}
\hline & Total & Mean & Range & Median \\
\hline PLC slides & 30,674 & 614 & $0-11,076$ & 38 \\
\hline Glass slides & 28,426 & 569 & $0-10,980$ & 24 \\
\hline
\end{tabular}

Abbreviation: $\mathrm{PLC}=$ poly-L-lysine coated

\section{DISCUSSION}

Leptomeningeal metastases are an important complication of systemic cancer. ${ }^{3}$ Once the diagnosis is suspected, it may be confirmed by the identification of malignant cells in the CSF. ${ }^{1.2,4.5 .7}$ But although cytology of CSF is an excellent test, $15-20 \%$ of the strongly suspected cases remain negative even after repeated cytological examinations. ${ }^{5.7}$ One reason for this low sensitivity of diagnostic cytology is the small number of cells on the glass slides. ${ }^{3.69}$ To improve the cytological assessment of the CSF, we used PLC slides for cytospin preparations. The principle behind this type of coating is that the cationic poly-L-lysine coated slide combines with the anionic sites on the cell surfaces, causing a stronger attachment of the cells to the surface of the slide. This has been studied for urine samples, buccal smears and fine needle aspirates, but the usefulness of PLC slides in diagnostic cytology of CSF has never been studied. ${ }^{11,12}$

Although we found a significant increase in the number of cells on the PLC slides to be evaluated, it changed the final diagnostic conclusion in only one case. In that case, we were able to establish the diagnosis of LMM, and therapy could be started. Although the differences in the numbers of cells were significant, the increase in the total cell number was only $8 \%$. It was especially the cytospin preparations with few cells, which failed to show a 
meaningful increase in the number of cells when a poly-L-lysine coating was used. If only differences of $10 \%$ or more were considered to be relevant, no significant difference in the numbers of cells on the two types of slides could be determined. This finding contrasts with the positive results found for urine samples and buccal smears, in which a poly-L-lysine coating led to a much greater increase in the number of cells on slides. ${ }^{11,12}$ This might be explained by the low levels of protein in these specimens, while the high protein levels of the CSF might mask the poly-L-lysine residue and thus resulting in a lower affinity for the cells. In conclusion, a significantly higher number of cells were found when PLC slides were used in the diagnostic cytology of CSF, but this yielded only a slight improvement of the diagnostic cytology. Because of these results we think that PLC slides are not useful for cytospinning of CSF to improve the cytology of CSF.

\section{REFERENCES}

1. Chamberlain MC. New approaches to and current treatment of leptomeningeal metastases. Curr Opin Neurol 1994;7:492-500.

2. Posner JB. Neurologic complications of cancer. Philadelphia: FA Davis Comp, 1995:143-171.

3. Twijnstra A, Glass JP. Leptomeningeal metastasis from solid extracranial tumors - Clinical diagnosis and management. In: Twijnstra A, Keyser A, Ongerboer de Visser BW, eds. Neuro-oncology. Amsterdam: Elsevier Science Publ B.V.,1993:257-265.

4. Wasserstrom WR, Glass JP, Posner JB. Diagnosis and treatment of leptomeningeal metastases from solid tumors: experience with 90 patients. Cancer 1982;49:759-772.

5. Van Heerde P. Leptomeningeal metastasis from solid extracranial tumors - Cytology of cerebrospinal fluid. In: Twijnstra A, Keyser A, Ongerboer de Visser BW, eds. Neuro-oncology. Amsterdam: Elsevier Science Publ B.V.,1993:266-271.

6. Koss LG. Diagnostic cytology and its histopathologic bases. $3^{\text {rd }}$ ed. Philadelphia: JB Lippincott, 1979: 971-988.

7. Olson ME, Chernik NL, Posner JB. Infiltration of the leptomeninges by systemic cancer. A clinical and pathologic study. Arch Neurol 1974;30:122-137.

8. Schumann GB, Crisman LG. Semiquantitative approach to CSF cytopathology. Diagn Cytopath 1986;2:194-197.

9. Bigner SH. Central nervous system. In: Bibbo M, ed. Comprehensive Cytopathology. Philadelphia: WB Saunders, 1991:468-483.

10. Dakin ES. Improved adhesion and visibility of cytologic preparations by use of the frosted glass slide. Science 1955;121:474-475.

11. Husain OAN, Millett JA, Grainger JM. Use of poly-L-lysine-coated slides in preparation of cell samples for diagnostic cytology with special reference to urine sample. J Clin Path 1980;33:309-311.

12. Mazia D, Schatten G, Sale W. Adhesion of cells to surfaces coated with poly-L-lysine. J Cell Biol 1975;66:198-200. 



\title{
CHAPTER 4
}

\author{
DETECTION OF MALIGNANT CELLS IN CEREBROSPINAL FLUID \\ USING FLUORESCENCE IN SITU HYBRIDIZATION
}

Presented at the $121^{\text {st }}$ meeting of the American Neurological Association; 14-05-1996, Miami, USA.

Adapted from:

RJ van Oostenbrugge, AHN Hopman, MH Lenders, P van Heerde, JW Arends, FCS Ramaekers, and A Twijnstra.

Detection of malignant cells in cerebrospinal fluid using fluorescence in situ hybridization. Journal of Neuropathology and Experimental Neurology 1997;56:743-748. 


\section{ABSTRACT}

Cytologic examination of cerebrospinal fluid (CSF) is the diagnostic gold standard for leptomeningeal metastases (LMM). However, this technique is only moderately sensitive when routine staining procedures are applied. The use of fluorescence in situ hybridization (FISH) to identify malignant cells may have an additional value in diagnosing LMM, since numerical chromosomal aberrations (NCA) can be detected at the single cell level.

We tested the feasibility of FISH to detect tumor cells in CSF by analyzing 22 samples with proven LMM with a probe for chromosome 1 (1q12) to detect NCA in the cells. A control group consisted of samples from 10 patients with inflammatory neurologic disease. In seven LMM samples no cells or only lysed cells were found, due to time delay before fixation.

Of the other 15 LMM samples analyzed, 13 showed NCA (87\%), while no NCA were found in the control group.

Our results indicate that FISH may be a useful additional diagnostic tool to the cytodiagnosis of CSF in cases of LMM. We expect that FISH can become an additional marker for malignancy at the single cell level in patients with LMM, which may also be of use to determine the effect of therapy for LMM. 


\section{INTRODUCTION}

Leptomeningeal metastases (LMM) are an important and often disabling neurological complication of cancer. ${ }^{1,2}$ The total incidence of LMM is unknown, but autopsy data have shown that it occurs in approximately $8 \%$ of patients with systemic cancer. ${ }^{3}$ LMM develops in $7-15 \%$ of patients with non-Hodgkin lymphoma and in $5-15 \%$ of patients with leukemia. Adenocarcinomas are the most common solid tumors to metastasize to the leptomeninges. For example, breast cancer accounts for $22-64 \%$ of LMM in patients with solid tumors, followed by lung cancer (1-26\%) and malignant melanoma (7-15\%), 4 ,

Early identification and treatment of this complication of systemic cancer may prevent serious neurological symptoms. ${ }^{6}$ When LMM is suspected, it can be confirmed by the identification of malignant cells in the cerebrospinal fluid (CSF) ${ }^{1,2,6,7}$, but even after repeated cytological examinations $15-20 \%$ of the suspected cases remain negative when conventional staining procedures are applied in the cytodiagnostic approach. ${ }^{1,7,8}$ The reasons for this large number of false-negative cases include the morphological resemblance between malignant cells and ependymal cells, the non-malignant aspect of lymphocytes in leptomeningeal localization of non-Hodgkin lymphoma or leukemia, the presence of blood cells due to traumatic lumbar puncture, and the fact that often only a small number of cells can be evaluated. ${ }^{9,10}$ Because a negative cytological examination does not exclude LMM, additional diagnostic tests have been proposed, including biochemical marker assays ${ }^{11}$, immunocytochemistry ${ }^{12,13}$, flow cytometric detection of aneuploidy ${ }^{14}$, the polymerase chain reaction in cases of LMM of leukemia with known genetic alterations ${ }^{15}$ and neuro-imaging techniques using magnetic resonance. ${ }^{16,17}$ Although these diagnostics can support the diagnosis, the sensitivity of these tests did not turn out to be high enough to improve the diagnosis of $\mathrm{LMM}^{2,5}$

Since genomic aberrations often parallel malignancy, the in situ hybridization (ISH) technique, by which chromosomal changes can be detected in interphase nuclei by using specific DNA probes, has been suggested as a possible additional diagnostic aid. Due to recent developments, for example the generation of different types of probes and the development of different pretreatment steps, this technique can indeed become an important adjunct in the diagnosis of malignancy. ${ }^{18-21}$ This procedure has so far been applied to cytological specimens of fine needle aspirates of various neoplasms ${ }^{22}$, bone marrow aspirates $^{23}$ and bladder washes ${ }^{24}$ to detect numerical chromosomal aberrations (NCA), but until now it was not used in the cytodiagnosis of CSF. We tested the feasibility and usefulness of ISH in CSF of 22 patients with cytologically proven LMM of systemic cancer and in ten controls with non-malignant disorders. A centromeric DNA probe for chromosome 1 (1q12) was applied to detect aneuploid cells, because of the high percentage of breast carcinoma cases in our series and the finding that in this type of cancer numerical aberrations for chromosome 1 can be detected in more than $80 \%$ of the cases. ${ }^{25-27}$ 


\section{MATERIALS AND METHODS}

\section{PATIENT MATERIAL}

CSF samples were obtained from 22 patients with LMM of systemic cancer (12 breast carcinomas, 1 melanoma, 4 non-Hodgkin lymphomas, 2 leukemia's, 1 ependymoma, 1 small-cell lung carcinoma and 1 unknown primary tumor) by lumbar puncture, using a 20 gauge syringe. All samples were Giemsa stained and judged to be malignant by two experienced pathologists (PvH, JWA). A disease control group consisted of 10 patients with proven bacterial $(n=7)$ or viral $(n=3)$ meningitis.

\section{IN SITU HYBRIDIZATION}

The aliquots from the CSF of the patients with LMM and the control group were either treated with pepsin prior to cytospin preparation or after cytocentrifugation. Pretreatment of the cytological specimen was done as described earlier. ${ }^{28.29}$ Cells were treated for 20 minutes at $37^{\circ} \mathrm{C}$ in $100 \mu \mathrm{g}$ pepsin (from Porcine stomach, 2500-3500 units per mg protein; Sigma, St. Louis, USA) per $\mathrm{ml} 0.01 \mathrm{~N} \mathrm{HCl}$ to make the cells more accessible to the DNA probes. Following the pepsin digestion step, the slides were air dried at room temperature and thereafter dehydrated in an acidified ethanol series. After dehydration, the cells were fixed in $1 \%$ formaldehyde in phosphate-buffered saline (PBS) for 15 minutes at $4^{\circ} \mathrm{C}$.

After fixation, the coated glass slides were washed twice in PBS and subsequently dehydrated in $70 \%, 90 \%$ and $100 \%$ ethanol.

In situ hybridization was performed essentially as described by Hopman et al. ${ }^{28}$

The centromeric DNA probe for chromosome 1 (1q12, pUC 1.77; Cooke and Hindley ${ }^{30}$ ) was hybridized in single-target ISH in a hybridization buffer containing $2 x S S C(0.15 \mathrm{NaCl}, 15$

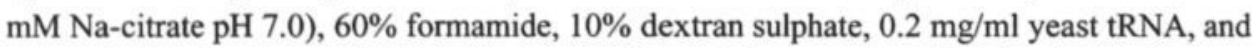
$0.2 \mathrm{mg} / \mathrm{ml}$ herring sperm DNA under a coverslip, and denatured at $70^{\circ} \mathrm{C}$ for three minutes. Thereafter, the slides were placed in a moist chamber and incubated overnight at $37^{\circ} \mathrm{C}$. The slides were then washed two times in $2 \mathrm{x} \mathrm{SSC} / 0,05 \%$ Tween at $45^{\circ} \mathrm{C}$, once in $0.1 \mathrm{x} \mathrm{SSC}$ at $60^{\circ} \mathrm{C}$ and finally once in $4 \mathrm{xSSC} / \mathrm{Tween} 0.05 \%$ at room temperature.

The biotinylated chromosome 1 probe was detected with fluorescein-isothiocyanate (FITC) conjugated to avidin (Vector Laboratories, Burlingame, USA). If necessary, the signal was intensified by a subsequent incubation with biotinylated goat-anti-avidin (Vector Lab.) and avidin-FITC (Vector Lab.)

Nuclear counterstaining was done with 4,6-diamino-2-phenylindole (DAPI;Sigma, St. Louis, USA).

\section{SLIDE EVALUATION}

Because of the low number of cells that could be analyzed in the CSF samples, no cut-off level for abnormality could be assessed. The following criteria were applied to assess the validity of specific chromosomal aberrations ${ }^{28}$ : 
a) overlapping nuclei are not included in the evaluation;

b) nuclei should have more or less the same FISH signal intensity;

c) the nucleus is DAPI-positive;

d) the nucleus has a low autofluorescence background;

e) nuclear morphology should be acceptable.

Samples were classified as disomic if no cells with more than two FISH signals were observed. If cells with more than two FISH signals were observed, they were regarded as aberrant if the above criteria applied, and were then classified as trisomic, tetrasomic or polysomic. Since in the case of four signals per cell one might argue that cells with this chromosome content represent the $\mathrm{G} 2 / \mathrm{M}$ phase of the cell cycle, we refer to Beck et al ${ }^{31}$ who have proven that normal G2/M cells exhibit only two signals per chromosome.

\section{FLUORESCENCE DETECTION AND PHOTOGRAPHY}

Fluorescence microscopy was performed using a Leica-DMBRE microscope equipped with the appropriate epifluorescence filter set for FITC and DAPI. Images were captured and stored with the Metasystem Image Pro System (Heidelberg, Germany), including a black and white charge-coupled device (CCD) camera.

\section{RESULTS}

\section{CONTROL SAMPLES}

The 10 control samples contained large numbers of cells that could be analyzed (at least 100 nuclei per sample). These cases, diagnosed as infectious neurological disease, showed no $\mathrm{NCA}$, in that cells with more than two FISH signals were not detected. Figure 1 (p.48) shows an example of the FISH results on cells in the CSF of a patient with bacterial meningitis, revealing mainly disomic cells.

Although no malignant cells were found in these samples, occasionally a few cells showed cytodiagnostically slightly atypical features, which were, however, not interpreted as an abnormality because of the large number of normal white blood cells. The percentage of cells showing one FISH signal ranged from $2-17 \%$ which is to be expected on the basis of colocalisation of chromosome targets or interpretation problems. Overall, the cytomorphology of these benign samples was better than that of the malignant ones. The FISH signals were of good quality, with minimal differences in fluorescence intensity.

\section{MALIGNANT SAMPLES}

The cytological parameters that established the diagnosis of LMM, as well as the FISH results and the relevant morphological aspects of the cells evaluated by FISH, are summarized in table 1 (p. 46). Cytological diagnosis of malignancy was not only based on nuclear aspects 
Table 1. Summary of cytodiagnostic parameters and FISH results of the 32 CSF samples used in this study.

\begin{tabular}{|c|c|c|c|c|}
\hline $\begin{array}{l}\text { Case } \\
\mathrm{Nr} \text {. }\end{array}$ & $\begin{array}{l}\text { Primary } \\
\text { diagnosis }\end{array}$ & $\begin{array}{l}\text { CSF } \\
\text { cytodiagnosis }\end{array}$ & $\begin{array}{l}\text { Morphology after } \\
\text { FISH }\end{array}$ & $\begin{array}{l}\text { Results of } \\
\text { FISH }\end{array}$ \\
\hline $1-10$ & $\begin{array}{l}\text { infectious } \\
\text { neurologic } \\
\text { disease }\end{array}$ & $\begin{array}{l}\text { no } \\
\text { malignancy }\end{array}$ & & disomy \\
\hline 11 & breast cancer & $1,3,5,6,9$ & $\begin{array}{l}\text { poor, lysis with } \\
\text { normal cells }\end{array}$ & $\begin{array}{l}\text { trisomy, } \\
\text { tetrasomy, } \\
\text { polysomy }\end{array}$ \\
\hline 12 & breast cancer & $1,2,5$ & good & $\begin{array}{l}\text { trisomy, } \\
\text { tetrasomy, } \\
\text { polysomy }\end{array}$ \\
\hline 13 & breast cancer & $2,4,6$ & moderate & trisomy \\
\hline 14 & breast cancer & $1,2,5$ & $\begin{array}{l}\text { good, malignant cells } \\
\text { recognizable }\end{array}$ & trisomy \\
\hline 15 & breast cancer & $1,2,6,9$ & good & $\begin{array}{l}\text { trisomy, } \\
\text { tetrasomy }\end{array}$ \\
\hline 16 & breast cancer & $1,4,7,9$ & lysis and normal cells & tetrasomy \\
\hline 17 & breast cancer & $1,2,3,6,9$ & poor & $\begin{array}{l}\text { tetrasomy, } \\
\text { trisomy }\end{array}$ \\
\hline 18 & breast cancer & $1,2,4,5$ & lysis & disomy \\
\hline 19 & breast cancer & $1,2,6$ & $\begin{array}{l}\text { poor, lysis and dry } \\
\text { artefacts }\end{array}$ & NE \\
\hline 20 & breast cancer & $1,4,5$ & lysis with normal cells & $\begin{array}{l}\text { tetrasomy, } \\
\text { polysomy }\end{array}$ \\
\hline 21 & breast cancer & 2,3 & good & tetrasomy \\
\hline 22 & breast cancer & $1,2,5$ & no cells & $\mathrm{NE}$ \\
\hline 23 & SCLC & $1,4,6,9$ & good & trisomy \\
\hline 24 & ependymoma & 1,4 & lysis & $\mathrm{NE}$ \\
\hline 25 & melanoma & 2,5 & lysis & NE \\
\hline 26 & NHL & $1,2,7,8$ & no cells & $\mathrm{NE}$ \\
\hline 27 & NHL & $1,2,8$ & good & trisomy \\
\hline 28 & NHL & $1,5,8$ & good & trisomy \\
\hline 29 & NHL & $1,4,5,8$ & good & disomy \\
\hline 30 & ALL & $3,4,6,8$ & lysis, no normal cells & $\mathrm{NE}$ \\
\hline 31 & ALL & $1,3,4,6,8$ & lysis, no normal cells & $\mathrm{NE}$ \\
\hline 32 & unknown & $2,4,5,6$ & good & trisomy \\
\hline
\end{tabular}

Abbreviations: FISH: fluorescence in situ hybridization; NE: not evaluable;

CSF: cerebrospinal fluid; SCLC: small-cell lung cancer; ALL: acute lymphoblastic leukemia; NHL: non-Hodgkin lymphoma.

Cytodiagnostic criteria (nr. 1-9: 1) Increased cell number, i.e. more than 10 cells per $\mu$;

2) Anisokaryosis; 3) Hyperchromatism; 4) Polymorphism; 5) Nucleolus present; 6) Increased nuclear-cytoplasmic ratio; 7) Mitotic figures; 8) Atypical lymphoid cells; 9) Clusters of cells. 
such as hyperchromatism or anisokaryosis, but also on features such as an increased nuclear-cytoplasm ratio, increased cell number and the presence of clusters of cells. Only 15 of the 22 cases could be analyzed by FISH because of the absence of cells in two cases and the presence of lysed cells in five cases. Cell lysis was judged to be present when the nucleus had lost its integrity or its morphology. Lysis of cells was present mostly in those samples subjected to a longer time delay (up to 24 hours) before fixation. Thirteen of the 15 evaluable malignant samples (87\%) showed varying numbers of cells with increased FISH signal numbers, ranging from three to seven signals per cell.

Figures 2 - 4 (p. 48) show several examples of FISH results obtained with the chromosome 1 probe in cells of CSF samples of patients with LMM. Figure 2 shows a trisomic cell surrounded by disomic cells in a case of LMM of breast cancer. Figure 3 shows intact nuclei with two and three FISH signals in a case of LMM of breast cancer. These cells are surrounded by lysed cells in which no conclusive FISH signal could be observed.

Figure 4, finally illustrates the FISH results in cells from the CSF of a patient with LMM of breast cancer. Cells with five and seven FISH signals can be seen and a cluster of cells is also present.

In two cases (nr. 18 and 29) only cells with two FISH signals for chromosome 1 were observed. To test the feasibility of a repeated FISH analysis on the same slide, incubation with a centromeric DNA probe for chromosome 15 was performed after removal of the hybridized probe for chromosome 1 in one of these cases (nr. 18). The same hybridization protocol was used to detect NCA for chromosome 15. In this case we could demonstrate a trisomy for chromosome 15 .

\section{PITFALLS}

Several methodological problems and pitfalls became apparent during our study. One of the most serious problems that were met was loss of good cytomorphology, mainly due to time delay before fixation of the CSF-samples. Because of cell lysis, the difference in fluorescence intensity was relatively high and the discreteness of the FISH signals was lost.

\section{Discussion}

Suspected LMM of systemic cancer is usually confirmed by the identification of malignant cells in the CSF. ${ }^{1,2,47}$ Since a negative cytodiagnostic result does not exclude LMM, we undertook a study to test the feasibility and diagnostic value of the FISH technique to increase the sensitivity of CSF examination. The FISH method has been applied to several solid tumor types ${ }^{18,19,20,32,33}$, and it has also been used to detect neoplastic cells present in cytological specimens, such as fine needle aspirates, bone marrow aspirates and bladder washes. ${ }^{22-24}$ 

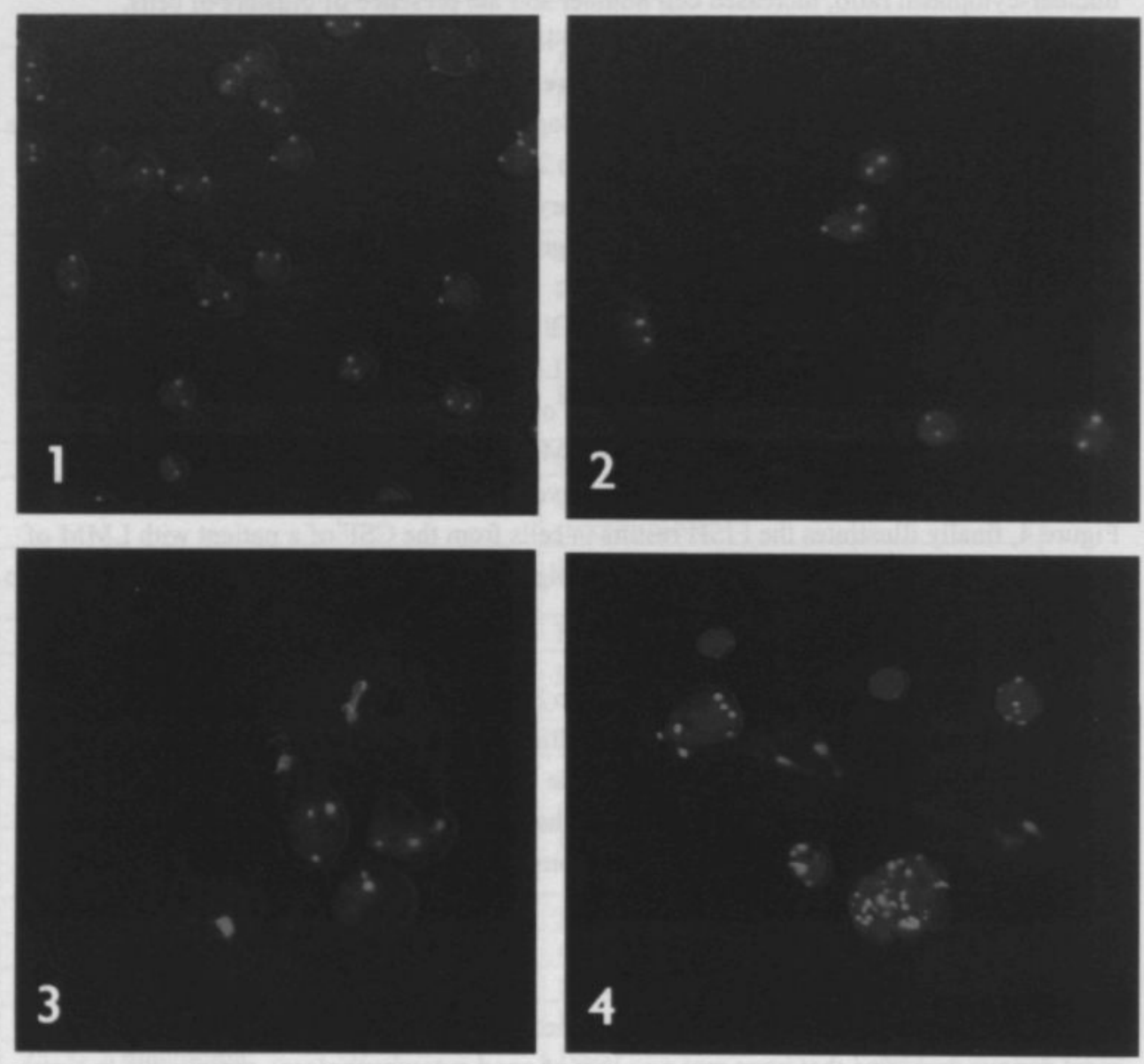

Fig. 1: Preparation of a control CSF sample of a patient with bacterial meningitis showing only disomic cells for chromosome 1 .

Fig. 2 - 4: CSF cells of three different breast carcinoma patients with LMM. Fig. 2 shows a trisomic cell surrounded by disomic cells. Fig. 3 shows a trisomic cell surrounded by disomic and lysed cells in which no conclusive FISH signal could be obtained. Fig. 4 shows polysomic cells ( 5 and 7 signals) next to clustered cells.

The centromeres of chromosome 1 were detected by FISH using a DNA probe for the heterochromatin region 1q12 (green signals). DNA was counterstained with DAPI (blue). 
CSF is almost ideally suited for evaluation by FISH, because the cells present are already in suspension, so that minimal sample preparation is required.

In this study, we selected the chromosome 1 probe (1q12) to detect aneuploid cells of LMM in CSF, mainly because our series contained a high number of cases of LMM of breast cancer, in which chromosome 1 aberrations are frequently observed. ${ }^{25-27}$ We were able to demonstrate NCA in $87 \%$ of the evaluable cases with cytologically proven malignant cells, while none of the benign samples could be classified as abnormal (aneusomic) on the basis of the FISH procedure. The finding of $2-17 \%$ cells with one FISH signal in this control group is not a sign of abnormality, but a result of colocalisation of chromosomal targets or problems in the macroscopic evaluation of the FISH signals. It seems reasonable therefore to expect that the FISH technique can be informative in CSF cases where no malignancy can be demonstrated after routine cytodiagnosis.

The number of cases in which aberrations are detected might be increased by using more than just one probe, either in a repeated FISH procedure or by simultaneous hybridization with differently labelled probes. For this reason we performed a repeated FISH incubation in one case, using the same slide but with a different centromeric DNA probe, and were able to show NCA in this way. Furthermore, although a relatively large number of NCA were found in lymphomas, detection of specific translocations may increase the sensitivity of the FISH procedure applied to cells in CSF in cases of LMM of lymphomas. It may be obvious that the choice of the DNA probes depends strongly on the type of malignancy. If samples of the primary tumor are available, these can be used to screen an extended set of probes for selection of a specific marker to be applied to CSF cells.

When comparing the results of routine cytodiagnostic procedures with the FISH classification, the following two aspects should be kept in mind. The diagnostic results obtained by routine cytopathology are not only based on nuclear aspects, but also on other criteria, such as the presence of clusters of cells, increased cell numbers, and a high nuclear-cytoplasmic ratio. ${ }^{10,34}$ These features are not evaluable with the FISH procedure. Therefore, we propose to perform a FISH analysis on the Giemsa-stained slide that was used for routine cytodiagnosis in order to detect NCA as a sign of malignancy whenever the cytodiagnostic evaluation reports atypical cells suspect for malignancy. Secondly, in our experience interpretable FISH results are only obtained if there is proper cell morphology. Dux et $\mathrm{al}^{35}$ showed that within 90 minutes after lumbar puncture $90 \%$ of the cells were lysed when CSF was kept at room temperature.

Studies on the diagnostic utility of aneuploidy detection in CSF have been performed before. Cibas et $\mathrm{al}^{14}$ detected DNA abnormalities in $69 \%$ of cases by using flow cytometry (FCM). The FISH technique has several advantages for detecting DNA abnormalities over FCM. Firstly, FCM requires a larger number of cells, whereas FISH can be performed at the single cell level. Secondly, tetrasomic cell lines are not easily recognized with FCM or mistaken for G2/M cells, whereas FISH does detect these cells. One might argue that in the case of four chromosome signals per cell, these cells represent the G2/M phase of normal cells. Beck et al have, however, proven that normal G2/M cells exhibit two signals when using the 1q12 probe and that no evident duplication of spot numbers occurs during DNA replication." 
In conclusion, this study demonstrates the feasibility of using FISH on cells from CSF to detect NCA for the identification of malignancy. This technique may have additional value in the cytopathological evaluation of CSF, as has already been demonstrated for other cytological preparations. FISH is particular suited for CSF analysis, because of the often small number of malignant cells in the preparations.

\section{REFERENCES}

1. Olson ME, Chernik NL, Posner JB. Infiltration of the leptomeninges by systemic cancer. A clinical and pathologic study. Arch Neurol 1974;30:122-137.

2. Posner JB. Neurologic complications of cancer. Philadelphia: FA Davis Comp, 1995:143-171.

3. Little JR, Dale AJ, Okazaki H. Meningeal carcinomatosis. Clinical manifestations. Arch Neurol 1974;30:138-143.

4. Wasserstrom WR, Glass JP, Posner JB. Diagnosis and treatment of leptomeningeal metastases from solid tumors: experience with 90 patients. Cancer 1982;49:759-772.

5. Chamberlain MC. New approaches to and current treatment of leptomeningeal metastases. Curr Opin Neurol 1994;7:492-500.

6. Twijnstra A, Glass JP. Leptomeningeal metastasis from solid extracranial tumors. In: Twijnstra A, Keyser A, Ongerboer de Visser BW, eds. Neuro-oncology. Amsterdam: Elsevier Science Publ B.V., 1993:257-265.

7. Glass JP, Melamed M, Chernik NL, Posner JB. Malignant cells in cerebrospinal fluid (CSF): the meaning of a positive CSF cytology. Neurology 1979;29:1369-1375.

8. Bigner SH, Johnston WW. The cytopathology of cerebrospinal fluid. II. Metastatic cancer, meningeal carcinomatosis and primary central nervous system neoplasms. Acta Cytol 1981;25:461-480.

9. Van Heerde P. Cytology of cerebrospinal fluid. In: Twijnstra A, Keyser A, Ongerboer de Visser BW, eds. Neuro-oncology. Amsterdam: Elsevier Science Publ B.V., 1993:266-271.

10. Bigner SH. Central nervous system. In: Bibbo M, ed. Comprehensive cytopathology. Philadelphia: WB Saunders Comp, 1991:468-483.

11. Twijnstra A. Cerebrospinal fluid biochemical markers in central nervous system metastasis: clinical applications. Thesis. University of Maastricht, The Netherlands, 1986.

12. Yam LT, English MC, Janckila AJ, Ziesmer S, Li CY. Immunocytochemistry of cerebrospinal fluid. Acta Cytol 1987;31:825-833.

13. Boogerd W, Vroom ThM, Van Heerde P, Brutel de la Rivière G, Peterse JL, Van der Sande JJ. CSF cytology versus immunocytochemistry in meningeal carcinomatosis. JNNP 1988;51:142-145.

14. Cibas ES, Malkin MG, Posner JB, Melamed MR. Detection of DNA abnormalities by flow cytometry in cells from cerebrospinal fluid. Am J Clin Pathol 1987;88:570-577.

15. Rhodes $\mathrm{CH}$, Glantz MJ, Glantz L, et al. A comparison of polymerase chain reaction examination of cerebrospinal fluid and conventional cytology in the diagnosis of lymphomatous meningitis. Cancer 1996;77:543-548.

16. Sze G, Soletsky S, Bronen R, Krol G. MR Imaging of the cranial meninges with emphasis on contrast enhancement and meningeal carcinomatosis. AJNR 1989;10:965-975.

17. Freilich RJ, Krol G, De Angelis LM. Neuroimaging and cerebrospinal fluid cytology in the diagnosis of leptomeningeal metastasis. Ann Neurol 1995;38:51-57. 
18. Gray JW, Pinkel D. Molecular cytogenetic in human cancer diagnosis. Cancer 1992;69:1536-1541.

19. Joos S, Fink TM, Rätsch A, Lichter P. Mapping and chromosome analysis: the potential of fluorescence in situ hybridization. J Biotech 1994;35:135-153.

20. Hopman AHN, Voorter CEM, Ramaekers FCS. Detection of genomic changes in cancer by in situ hybridization. Mol Biol Reports 1994;19:31-44.

21. Bentz M, Döhner $\mathrm{H}$, Cabot $\mathrm{G}$, Lichter P. Fluorescence in situ hybridization in leukemias: "the FISH are spawning!". Leukemia 1994;8:1447-1452.

22. Cajulis RS, Frias-Hidvegi D. Detection of numerical chromosomal abnormalities in malignant cells in fine needle aspirates by fluorescence in situ hybridization of interphase cell nuclei with chromosome-specific probes. Acta Cytol 1993;37:391-396.

23. Miranda RN, Mark HFL, Medeiros LJ. Fluorescent in situ hybridization in routinely processed bone marrow aspirate clot and core biopsy sections. Am J Pathol 1994;145:1309-1314.

24. Cajulis RS, Haines GK, Frias-Hidvegi D, McVary K, Bacus JW. Cytology, flow cytometry, image analysis and interphase cytogenetics by fluorescence in situ hybridization in the diagnosis of transitional cell carcinoma in bladder washes: a comparative study. Diagn Cytopathol 1995;13:214-224.

25. Devilee P, Thierry RF, Kievits T, et al. Detection of chromosome aneuploidy in interphase nuclei from human primary breast tumours using chromosome-specific repetitive DNA probes. Cancer Res 1988;48:5825-5830.

26. Dutrillaux B, Gerbault-Seureau M, Zafrani B. Characterization of chromosomal anomalies in human breast cancer. A comparison of 30 paradiploid cases with few chromosome changes. Cancer Genet Cytogenet 1990;49:203-217.

27. Harrison M, Magee HM, O'Loughlin J, Gorey TF, Dervan PA. Chromosome 1 aneusomy, identified by interphase cytogenetics in mammographically detected ductal carcinoma in situ of the breast. J Pathol 1995;175:303-309.

28. Hopman AHN, Poddighe P, Moesker O, Ramaekers FCS. Interphase cytogenetics: an approach to the detection of genetic aberrations in tumours. In: Herrington CS, Mc Gee J O'D, eds. Diagnostic molecular pathology. A practical approach, vol. 1. Oxford: IRL Press, 1992:141-167.

29. Poddighe PJ, Bringuier PP, Vallinga M, Schalken JA, Ramaekers FCS, Hopman AHN. Loss of chromosome 9 in tissue sections of transitional cell carcinomas as detected by interphase cytogenetics. A comparison with RFLP analysis. J Pathol 1996;179:169-176.

30. Cooke HJ, Hindley J. Cloning of human satellite III DNA: different components are on different chromosomes. Nucleic Acid Res 1979;6:3177-3197.

31. Beck JLM, Hopman AHN, Vooys GP, Ramaekers FCS. Chromosome detection by in situ hybridization in cancer cell populations which were flow cytometrically sorted after immunolabeling. Cytometry 1992;13:346-355.

32. Poddighe PJ, Ramaekers, FCS, Hopman AHN. Interphase cytogenetics of tumours. J Pathol 1992;166:215-224.

33. Lichter P, Boyle AL, Cremer T, Ward DC. Analysis of genes and chromosomes by non-isotopic in situ-hybridization. Anal Technol Appl 1991;8:24-35.

34. Koss LG. Diagnostic cytology and its histopathologic basis. Philadelphia: JB Lippincott Comp, 1979:971-988. 
35. Dux R, Kindler-Röhrborn A, Annas M, Faustmann P, Lennartz K, Zimmerman CW. A standardized protocol for flow cytometric analysis of cells isolated from cerebrospinal fluid. J Neurol Sci 1994;121:74-78. 


\section{CHAPTER 5}

IDENTICAL CHROMOSOMAL ABERRATIONS ARE FOUND IN MALIGNANT

CELLS IN CEREBROSPINAL FLUID AND THEIR CORRESPONDING

LEPTOMENINGEAL METASTASES AND PRIMARY TUMORS

Adapted from:

RJ van Oostenbrugge, A Twijnstra, MIJ Ummelen, B Krijne-Kubat, FCS Ramaekers and AHN Hopman.

Identical chromosomal aberrations are found in malignant cells in cerebrospinal fluid and their corresponding leptomeningeal metastases and primary tumors.

Submitted. 


\section{ABSTRACT}

In order to demonstrate that the tumor cells in the cerebrospinal fluid (CSF) represent the malignant cells in the leptomeningeal metastases (LMM) we studied the resemblance between the numerical content of chromosomes 1, 7, and 10 in malignant cells present in the CSF and the corresponding LMM and primary tumors. The copy numbers of individual chromosomes in cells from the various anatomic sites were determined in five cases, using the in situ hybridization (ISH) technique. The malignant CSF cells and LMM were disomic in two cases, while in the three other cases identical copy numbers of the chromosomes studied were detected in the cells derived from the three anatomic sites. These results demonstrate that identical numerical chromosomal aberrations can be detected by ISH in malignant cells from the CSF, LMM and primary tumor in the same patient. This finding supports the assumption that cells in the CSF are indeed shed from the LMM and that the chromosomal aberration detected in these cells represents that in the LMM. 


\section{INTRODUCTION}

Malignant leptomeningeal infiltration is characterized by superficial, sheat-like cell proliferation with infrequent invasion of the brain parenchyma mainly via perivascular growth. ${ }^{1,2}$ An inflammatory response causing infiltration of mononuclear cells is occasionally induced. ${ }^{2}$ Leptomeningeal metastases (LMM) are diagnosed by cytologic detection of malignant cells in the cerebrospinal fluid (CSF). ${ }^{3}$ In general, it is possible to establish a specific diagnosis based on the cytomorphologic resemblance between the primary tumor cells and the malignant cells in the CSF. ${ }^{4,5}$

In a recent study ${ }^{6}$, we demonstrated that detection of numerical chromosomal aberrations in cells from CSF by in situ hybridization (ISH) improves the cytodiagnostic efficiency in the recognition of LMM. By using this method cytologically atypical CSF cells in patients clinically suspected of LMM were classified as malignant, based on the presence of aneusomy.

To establish whether or not the tumor cells in CSF indeed represent the malignant cells present in the malignant leptomeningeal infiltration and thus from the primary tumor, we analyzed the copy number profile for chromosomes 1,7 , and 10 in five cases with LMM.

\section{MATERIALS AND METHODS}

Five patients known with systemic cancer and LMM were included in this study. LMM were diagnosed by the detection of malignant cells in the CSF by cytological examination.

CSF samples obtained during life were fixed in $70 \%$ ethanol and stored at $-20^{\circ} \mathrm{C}$. At autopsy, performed after informed consent from relatives, the brain and leptomeninges were directly fixed in buffered $5-10 \%$ formaldehyde for 2-3 weeks. Subsequently, standard paraffin sections of the brain and leptomeninges were made, which could be analyzed for routine histology and for the in situ hybridization (ISH) technique. The brains and leptomeninges of 15 patients without a history of cancer were also analyzed with the ISH method and used as controls.

If an aneusomy was found in the CSF cells, we studied the primary tumor and LMM. If no aneusomic cells were detected in the CSF, only the LMM were studied.

\section{Sample preparation.}

CSF samples were cytospinned for 10 minutes at $800 \mathrm{rpm}$. onto poly-L-lysine coated slides and air dried at room temperature. For the fluorescence ISH technique, the cytospinned CSF samples were pretreated with pepsin as described before. ${ }^{7}$

Paraffin sections ( $4 \mu \mathrm{m}$ thick) from the primary tumor and the LMM with underlying brain parenchyma were treated with $85 \%$ formic acid containing $0.3 \% \mathrm{H} 2 \mathrm{O} 2$ (Merck, Darmstadt, Germany) for 20 minutes at room temperature to block internal peroxidase activity. 
After dehydration with $70 \%$ ethanol in $0.01 \mathrm{~N} \mathrm{HCl}$, the sections were treated with $1 \mathrm{M}$ sodium thiocynate (Merck) at $80^{\circ} \mathrm{C}$ for 10 minutes and digested with $4 \mathrm{mg} / \mathrm{ml}$ pepsin from porcine stomach (2500-3500 units per mg protein; Sigma, St. Louis, USA) in $0.02 \mathrm{~N} \mathrm{HCl}$ at $37^{\circ} \mathrm{C}$ under microscopic evaluation. ${ }^{8}$ Finally, the slides were dehydrated in $70 \%$ ethanol in $0.01 \mathrm{~N} \mathrm{HCl}$.

\section{In situ hybridization procedure}

The ISH analysis used biotinylated DNA probes that hybridized to the (peri)centromeric regions of chromosome 1 (1q12, pUC 1.77, Cooke and Hindley $\left.{ }^{9}\right), 7$ (p7t1, Waye $\left.{ }^{10}\right)$, 10 (D10Z1, Devilee 11) and 17 (p17H8; Waye and Willard ${ }^{12}$ ). Chromosome 1 was studied because it is usually a sensitive marker for aneusomy, especially in cases of breast cancer. ${ }^{13}$ The copy number of chromosome 7 was analyzed because it is a good marker for general aneusomy in many tumor types including brain tumors. ${ }^{14}$ Chromosome 10 was studied because loss of copy number is an early event in tumorogenesis of malignant brain tumors. ${ }^{14}$ Finally, chromosome 17 was studied in the breast cancer case because loss of one copy occurs late in tumorogenesis. ${ }^{13}$ These probes were applied in hybridization buffer $(60 \%$ formamide, $2 \mathrm{xSSC} \mathrm{pH} 7.0,10 \%$ dextran sulphate, $0.2 \mathrm{mg} / \mathrm{ml}$ yeast tRNA and $0.2 \mathrm{mg} / \mathrm{ml}$ herring sperm DNA). The final concentration of the probe used for the CSF cells was $0.4 \mathrm{ng} / \mathrm{ml}$ DNA for pUC 1.77 and $1 \mathrm{ng} / \mathrm{ml}$ DNA for the other probes. DNA concentrations of $1.0 \mathrm{ng} / \mathrm{ml}$ and $2.0 \mathrm{ng} / \mathrm{ml}$ were used for the paraffin sections. Ten microliters of this mixture were added to the slides under a coverslip. Samples were then denatured in a moist chamber at $70^{\circ} \mathrm{C}$ for three minutes (CSF samples) or at $80^{\circ} \mathrm{C}$ for five minutes (paraffin sections). Hybridization took place overnight at $37^{\circ} \mathrm{C}$. Hereafter the CSF slides were washed once for 5 minutes in $0.1 \mathrm{xSSC}$ at $60^{\circ} \mathrm{C}$ and once for 5 minutes in $4 \mathrm{xSSC} / 0.05 \%$ Tween 20 at room temperature. Paraffin sections were washed twice for 5 minutes in $2 x S S C / 0.05 \%$ Tween 20 buffer $\mathrm{pH} 7.0$ at $42^{\circ} \mathrm{C}$, twice for 5 minutes in $0.1 \mathrm{xSSC}$ at $60^{\circ} \mathrm{C}$, and once in $4 \mathrm{x} \mathrm{SSC} / 0.05 \% \mathrm{~T}$ ween 20 at room temperature.

The biotinylated probes applied to the CSF samples were detected as described before 7 , using subsequent incubation steps with fluorescein isothiocyanate (FITC) conjugated avidin (Vector, Braunschwig Chemie, Amsterdam, The Netherlands), biotin-conjugated goat anti-avidin (Vector) and finally once more FITC-conjugated avidin, all for 20 minutes at $37^{\circ} \mathrm{C}$. Nuclei were counterstained with $0.5 \mu \mathrm{g} / \mathrm{ml}$ propium iodide (PI; Sigma).

The biotinylated probes applied to the sections were detected using subsequent incubations with monoclonal mouse-anti-biotin, biotinylated horse-anti-mouse, and avidin-biotin peroxidase complex. Peroxidase activity was demonstrated by a diaminobenzidine (DAB; Sigma) precipitation reaction.

The nuclei were counterstained using 4,6-diaminidino-2-phenylindole (DAPI; Sigma), dehydrated, and mounted in Entellan (Merck).

\section{Slide evaluation}

Hematoxylin-eosin stained sections of the primary tumor and leptomeninges were reviewed and the CSF samples were classified after Giemsa-staining. 
The ISH signals detected in the samples and sections were evaluated using the criteria described before. ${ }^{7,8}$ The cut-off percentage for an aberrant chromosome copy number in the sections was set at $5 \%$, whereas no cut-off value could be used in the CSF samples because of the low numbers of cells.

\section{Microscopy and microphotographs}

Fluorescence and bright-field microscopy was performed using a Leica-DMBRE microscope equipped with the appropriate (epifluorescence) filter sets. Microphotographs were recorded with the In Situ Image System (Metasystems GmbH, Altlussheim, Germany) using a black and white CCD camera.

\section{RESULTS}

Table 1 (p. 58) summarizes the histologic data of the primary tumor, the extent of leptomeningeal invasion and the results of CSF cytology, as well as the results of the ISH method in the primary tumors, LMM and CSF cells.

The primary tumors were classified as breast cancer $(n=1)$ and non-Hodgkin lymphoma $(n=4 ; N H L)$. Malignant leptomeningeal infiltration was found in all cases by histopathological examination at autopsy. In only two cases (nos. 1 and 4) was the malignant infiltration restricted to the leptomeninges, the pia-glia lamina being intact in both cases. In the other three cases (nos. 2, 3, and 5) superficial or deep cortical invasion was found, which had occurred via perivascular growth or parenchymal infiltration. In these three NHL cases the pia-glia lamina had been destroyed. One case (no. 5) also showed mononuclear infiltrates adjacent to the malignant cells in the leptomeninges.

In all five cases, the numerical chromosome constitution was found to be identical in the malignant cells present in CSF and LMM. In two cases (nos. 4 and 5) the cytologically malignant CSF cells and the malignant leptomeningeal infiltration were disomic for chromosomes 1 and 7. The primary tumors in these cases were not analyzed because of the expected disomic character of the malignancy.

In the remaining three cases, identical numerical chromosomal aberrations were detected in cells from the three anatomic sites. In case 1 , identical abnormal copy numbers of chromosomes 1,7 , and 10 were detected at the three sites. The copy number of chromosome 17 in cells from the three sites in this case of breast cancer was also determined and was found to be disomic. Figures 1 A-D (p. 59) show the results of the ISH procedure on cells in the CSF and the malignant leptomeningeal infiltration in case 1. Figs. $1 \mathrm{~A}$ and $\mathrm{B}$ show the results of fluorescence ISH on cells from CSF with DNA probes for chromosomes 1 and 7 , respectively. Tri-, tetra-, and polysomic cells can be seen (ISH signals in green; nucleus in red). Fig. $1 \mathrm{C}$ shows a hematoxylin-eosin stained section of the malignant infiltration of the leptomeninges. The square indicates the detail shown in fig. $1 \mathrm{D}$, which shows aneusomic cells detected by bright-field ISH using a DNA probe for chromosome 1. 
Table 1: Results of CSF cytology and microscopic pathology of the leptomeningeal metastases at autopsy and results of the in situ hybridization method in cells from the cerebrospinal fluid (CSF), leptomeningeal metastases (LMM), and primary tumor in five cases.

\begin{tabular}{|c|c|c|c|c|c|}
\hline Case & CSF cytology & Pathology LMM & ISH CSF cells & ISH LMM & ISH primary tumor \\
\hline $\begin{array}{c}1 \\
\text { breast } \\
\text { cancer }\end{array}$ & $\begin{array}{l}\text { malignant } \\
\text { carcinoma cells. }\end{array}$ & $\begin{array}{l}\text { malignant invasion restricted } \\
\text { to leptomeninges. No deep } \\
\text { parenchyma invasion. }\end{array}$ & $\begin{array}{l}\# 1,7 \text { and } 10 \text { tri-, tetra-, } \\
\text { and polysomy, } \\
\# 17 \text { disomy. }\end{array}$ & $\begin{array}{l}\# 1,7 \text { and } 10 \text { tri-, tetra-, } \\
\text { and polysomy; } \\
\# 17 \text { disomy. }\end{array}$ & $\begin{array}{l}\# 1,7 \text { and } 10 \text { tri-, tetra-, } \\
\text { and polysomy; } \\
\# 17 \text { disomy. }\end{array}$ \\
\hline $\begin{array}{c}3 \\
\mathrm{NHL}\end{array}$ & NHL cells. & $\begin{array}{l}\text { leptomeninges; destruction of } \\
\text { lamina; massive parenchyma } \\
\text { infiltration. }\end{array}$ & $\begin{array}{l}\# 1 \text { disomy; \#7 trisomy; } \\
\# 10 \text { trisomy. }\end{array}$ & $\begin{array}{l}\# 1 \text { disomy; \#7 trisomy; } \\
\# 10 \text { not evaluable. }\end{array}$ & $\begin{array}{l}\# 1 \text { disomy; \#7 trisomy; } \\
\# 10 \text { not evaluable. }\end{array}$ \\
\hline$\stackrel{4}{\mathrm{NHL}}$ & NHL cells. & $\begin{array}{l}\text { malignant invasion restricted } \\
\text { to leptomeninges. No deep } \\
\text { parenchyma invasion. }\end{array}$ & $\# 1$ and 7 disomy. & $\# 1$ and 7 disomy. & not done. \\
\hline $\begin{array}{c}5 \\
\mathrm{NHL}\end{array}$ & NHL cells. & $\begin{array}{l}\text { leptomeninges; destruction of } \\
\text { lamina; deep perivascular } \\
\text { growth; mononuclear } \\
\text { infiltrates. }\end{array}$ & $\# 1$ and 7 disomy. & $\# 1$ and 7 disomy. & not done. \\
\hline
\end{tabular}

Abbreviations: CSF: cerebrospinal fluid; LMM: leptomeningeal metastases; ISH: in situ hybridization; NHL: non-Hodgkin lymphoma; \#: chromosome. 

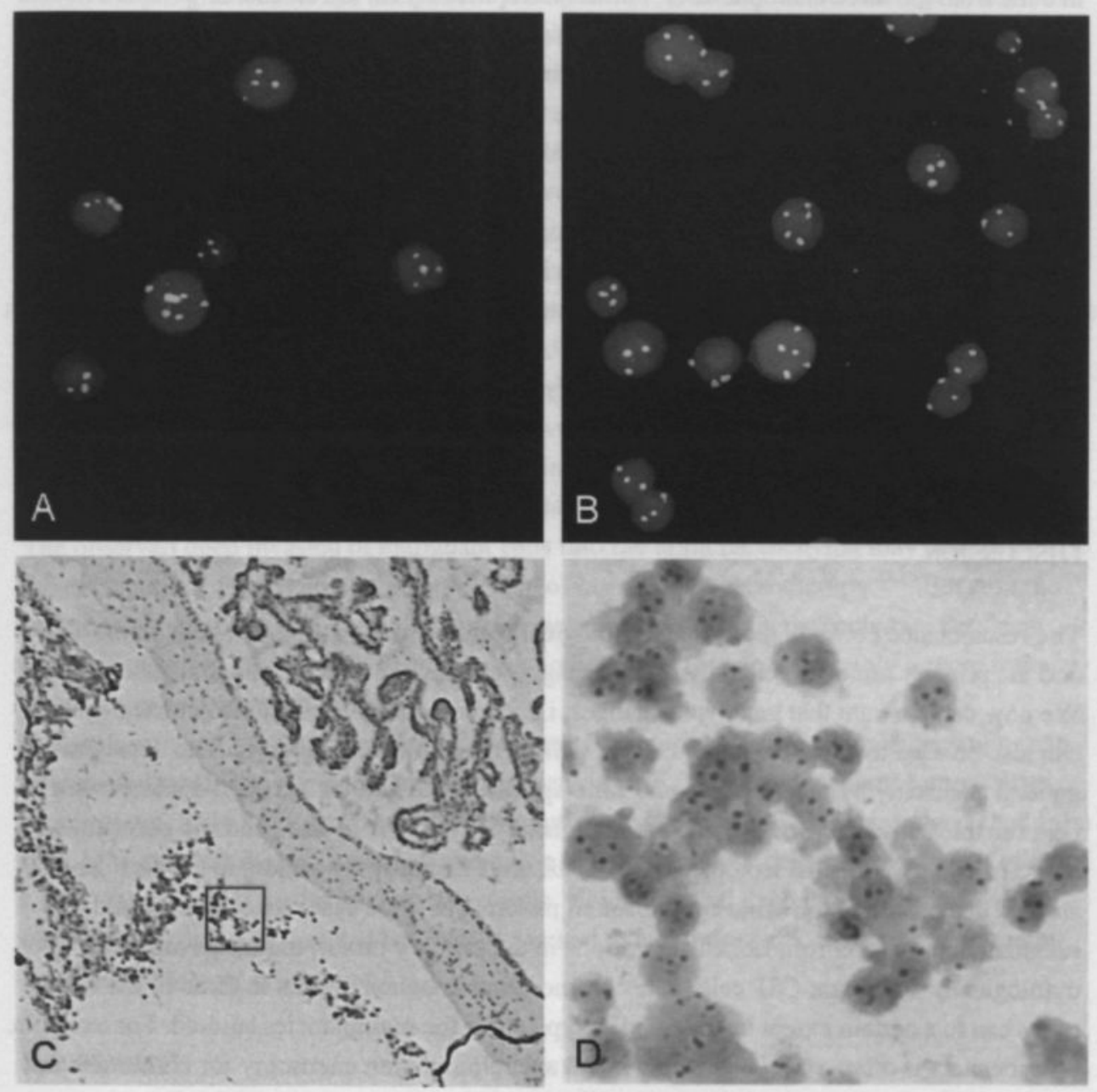

Fig. A and B: Preparation of a CSF sample of a breast cancer patient with LMM showing tri-, tetra-, and polysomic cells for chromosomes 1 and 7, respectively, detected by fluorescence ISH (signals in green). DNA was counterstained with PI (red). Fig. C: Section of malignant leptomeningeal infiltration, which was restricted to the leptomeninges. The square indicates the detailed view shown in fig. D, where tri- and tetrasomic cells detected by bright-field ISH using a DNA probe for chromosome 1 can be seen. 
In case 2, trisomy for chromosome 1 and tri- and tetrasomy for chromosome 7 were detected in cells from the three anatomic sites. Furthermore, trisomy for chromosome 10 was detected in the cells in CSF and at the LMM, whereas the ISH signals in the cells from the primary tumor were not evaluable. In case 3 trisomy for chromosome 7 was found in cells from the three sites, whereas only two ISH signals were observed for chromosome 1 . Trisomy for chromosome 10 could only be evaluated in CSF cells.

With respect to the leptomeninges, aneusomic cells were found in the pathologically confirmed malignant sites in the cases 1-3. Moreover, single, scattered aneusomic cells could also be detected deep in the brain parenchyma in case 1 . However, these cells could not be detected by routine histopathological examination. Furthermore, the pia glia lamina was intact at histopathological examination.

The leptomeninges of the 15 control cases only showed disomic cells for the centromeric DNA probes for chromosomes 1,7 , and 10.

\section{Discussion}

The resemblance between the cytomorphological features of the malignant cells in the CSF and the primary tumor is generally used to diagnose malignant leptomeningeal infiltration. ${ }^{4,5}$ We now demonstrate that genotypic changes, i.e. chromosomal aberrations detected by ISH, can also be used to correlate tumor cells in CSF to their solid counterparts. The detection of general aneusomy by means of chromosome-specific DNA probes has been demonstrated to be a reliable marker for the presence of malignancy in the CSF. ${ }^{7}$ The genomic constitution detected in the CSF cells, leptomeningeal metastases and primary tumors in the five cases studied demonstrated the same chromosomal patterns. In three cases we demonstrated identical numerical chromosomal aberrations in the primary tumor, the LMM and the cytologically malignant CSF cells. The chromosomal imbalances seen in three of the five cases can to a certain extent be regarded as typical for the malignancies studied. For example, breast cancer is often associated with general aneuploidy, with aneusomy for chromosome 1 being present in the majority of the cases. ${ }^{13}$ In the two other cases, the CSF cells were disomic for chromosomes 1 and 7, although cytology classified the CSF samples as malignant. In these two cases, the morphologically malignant sites at the leptomeninges showed no aberration for these chromosomes either.

Although we did not compare the total genomic content of the tumor cells at the different malignant sites, as can for example be done by comparative genomic hybridization, our results strongly suggest that cells exfoliating into the CSF do not differ chromosomally from the malignant cells in the leptomeningeal infiltration, as suggested by Jayson and Howell. ${ }^{15}$ In two cases (nos. 1 and 4), histopathological examination revealed the characteristic superficial growth pattern of malignant leptomeningeal infiltration to be confined to the leptomeninges. ${ }^{16,17,18}$ In the three remaining NHL cases deep invasion of brain parenchyma was also present, but, this was only found whenever the pia-glial membrane had been destroyed. This confirms the observations by Price and Johnson ${ }^{16}$, who studied patients with 
leukemic LMM and only found deep invasion of the neural parenchyma in those cases in which the pia-glia lamina had been destroyed by tumor. Contrary to the findings in leukemic LMM, Olson et $\mathrm{al}^{17}$ did not find deep parenchymal invasion in cases with LMM from solid tumors, although subpial parenchymal infiltration was occasionally found. We also found no infiltration by histomorphological criteria in the one case of solid tumor in our series, while isolated aneusomic cells could clearly be detected deep in the brain parenchyma by means of the ISH method. Thus, we must conclude that such scattered infiltrating cells are missed by routine histomorphological examination. Strikingly, the pia-glia lamina was still intact in this breast cancer case. But since no brain metastases could be demonstrated, it is most plausible that these cells originated from the LMM. As suggested by Mareel et $\mathrm{al}^{19}$, invasion occurs due to an imbalance between mechanisms involved in invasion-promotion and invasionsuppression. In this process, the ependymal lining of the leptomeninges seems to permit invasion of solid tumor cells, as has been shown in vitro by Pedersen et al. ${ }^{20}$ The ease with which solid tumor cells invaded the leptomeninges, and the absence of a barrier function of the pia-glial membrane was demonstrated in their study.

The observed deep invasion of malignant cells into the brain parenchyma may also be one of the explanations for the unsatisfactory results of intrathecal chemotherapy. ${ }^{21,22}$ Because the intrathecally administered drugs do hardly penetrate into the brain parenchyma, the deep invading cells are not reached. Systemic chemotherapy is therefore probably a more rational approach in patients with LMM.

In conclusion, we have demonstrated that identical numerical chromosomal aberrations can be detected by ISH in the malignant cells present in CSF, LMM and primary tumor in the same patient. This finding supports the assumption that cells in the CSF are indeed shed from the LMM and that the chromosomal aberration detected in these cells represents that of the LMM. Furthermore, scattered aneusomic cells, which invaded deep into the brain parenchyma, could be detected by the ISH method, while these cells could not be found by routine histological procedures.

\section{REFERENCES}

1. Chamberlain MC. Leptomeningeal metastases. In: Vecht $\mathrm{Ch}$ J, ed. Handbook of Clinical Neurology, Vol. 25 (69): Neuro-Oncology, Part III. Amsterdam: Elsevier Science B.V., 1997:151-165.

2. Ramsay DA. The meninges and their reaction to injury. In: Davis RL, Robertson DM, eds. Textbook of Neuropathology, 3rd ed, Baltimore: Williams \& Wilkins, 1997:207-224.

3. Glass JP, Melamed M, Chernik NL, Posner JB. Malignant cells in cerebrospinal fluid (CSF): The meaning of a positive CSF cytology. Neurology 1979;29:1369-1375.

4. An-Foraker SH. Cytodiagnosis of malignant lesions in cerebrospinal fluid. Review and cytohistologic correlation. Acta Cytol 1985;29:286-290.

5. Bigner SH. Central nervous system. In: Bibbo M, ed. Comprehensive cytopathology. Philadelphia: WB Saunders Comp, 1991:468-483.

6. Van Oostenbrugge RJ, Hopman AHN, Arends JW, Ramaekers FCS, Twijnstra A. The value of interphase cytogenetics in cytology for the diagnosis of leptomeningeal metastases.

Neurology 1998;51:906-908. 
7. Van Oostenbrugge RJ, Hopman AHN, Lenders MH, Van Heerde P, Arends JW, Ramaekers FCS, Twijnstra A. Detection of malignant cells in cerebrospinal fluid using fluorescence in situ hybridization. J Neuropath Exp Neurol 1997;56:743-748.

8. Hopman AHN, Ramaekers FCS. Processing and staining of cell and tissue material for interphase cytogenetics. In: Robinson JP, Darzynkiewicz Z, Dean PN, et al, eds. Current protocols in cytometry, Suppl. 5. New York: John Wiley \& Sons Inc., 1998:8.5.1-8.5.22.

9. Cooke HJ, Hindley J. Cloning of human satellite III DNA: different components are on different chromosomes. Nucleic Acid Res 1979;6:3177-3197.

10. Waye JS, England SB, Willard HF. Genomic organization of alpha satellite DNA on human chromosome 7: evidence for two distinct alphoid domains on a single chromosome . Mol Cell Biol 1987;7:349-356.

11. Devilee P, Kievits T, Waye JS, Pearson PL, Willard HF. Chromosome-specific alpha satellite DNA: isolation and mapping of a polymorphic alphoid repeat from human chromosome 10. Genomics 1988;3:1-7.

12. Waye JS, Willard HF. Molecular analysis of a deletion polymorphism in alphe satellite on human chromosome 17: evidence for homologous unequal crossing-over and subsequent fixation. Nucleic Acid Res;14:6915-6927.

13. Alers JC, Van Dekken H. Interphase cytogenetic analysis of solid tumors by non-isotopic DNA in situ hybridization. Progr Histochem Cytochem 1996;31:60-63.

14. Arnoldus EP, Wolters LB, Voormolen JH, et al. Interphase cytogenetics: a new tool for the

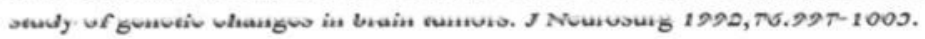

15. Jayson GC, Howell A. Carcinomatous meningitis in solid tumours. Ann Oncol 1996;7:773786.

16. Price RA, Johnsson WW. The central nervous system in childhood leukemia:I. The arachnoid. Cancer 1973;31:520-533.

17. Olson ME, Chernik NL, Posner JB. Infiltration of the leptomeninges by systemic cancer. A clinical and pathologic study. Arch Neurol 1974;30:122-137.

18. Lantos PL, Vandenberg SR, Kleihues P. Tumours of the central nervous system.

In: Graham DI, Lantos PL, eds. Greenfield's Neuropathology. 6th ed. New York: Oxford University Press Inc. 1997:787-791.

19. Mareel M, Leroy A, Bracke M. Cellular and molecular mechanisms of metastasis as applied to carcinomatous meningitis. J Neurooncol 1998;38:97-102.

20. Pedersen PH, Rucklidge GJ, Mørk SJ, et al. Leptomeningeal tissue: a barrier against brain tumor cell invasion. J Natl Cancer Inst 1994;86:1593-1599.

21. Siegal T, Lossos A, Pfeffer MR. Leptomeningeal metastases: analysis of 31 patients with sustained off-therapy response following combined-modality therapy.

Neurology 1994;44:1463-1469.

22. Bokstein F, Lossos A, Siegal T. Leptomeningeal metastases from solid tumors: a comparison of two prospective series treated with and without intra-cerebrospinal fluid chemotherapy.

Cancer 1998;82:1756-1763. 


\section{CHAPTER 6}

THE ADDITIONAL DIAGNOSTIC VALUE OF FLUORESCENCE IN SITU HYBRIDIZATION IN PATIENTS CLINICALLY SUSPECTED OF LEPTOMENINGEAL METASTASES

Presented at the $50^{\text {th }}$ annual meeting of the American Academy of Neurology, 30-04-1998, Minneapolis, USA.

Adapted from:

RJ van Oostenbrugge, AHN Hopman, JW Arends, FCS Ramaekers and A Twijnstra. The value of interphase cytogenetics in cytology for the diagnosis of leptomeningeal metastases.

Neurology 1998;51:906-908. 


\section{ABSTRACT}

We studied the use of the fluorescence in situ hybridization (FISH) technique in cerebrospinal fluid (CSF) to enhance the diagnostic yield for the detection of malignancy on the first lumbar puncture in patients clinically suspected of leptomeningeal metastases (LMM).

Although repeated lumbar punctures were still needed in some patients, the use of FISH did speed the diagnosis in about a third of the patients clinically suspected of LMM with atypical cells at first cytology. This eliminates the need for repeated lumbar punctures in these patients and enables an earlier start of treatment. 


\section{INTRODUCTION}

The cytologic detection of malignant cells in cerebrospinal fluid (CSF) is generally required for a definitive diagnosis of leptomeningeal metastases (LMM). However, cytodiagnosis of CSF using conventional staining procedures fails to detect malignant cells in up to $15 \%$ of the clinically suspected cases, even after repetitive lumbar punctures. ' None of the additional tests such as immunohistochemistry, biochemical tumormarker assays, and cytogenetic approaches has been found to significantly improve the diagnostic accuracy, due to their lack of sensitivity. 'The detection of aneusomy by interphase cytogenetics by means of fluorescence in situ hybridization (FISH) in various body fluids other than CSF has proved to be as sensitive as conventional cytodiagnostic procedures, and is recommended as a complement to routine cytologic examination. ${ }^{2}$ Recently, we have described that malignant cells can be detected in CSF by demonstrating aneusomy for chromosome 1 using the FISH method. ${ }^{3}$ The aim of this study was to establish the additional diagnostic value of the FISH technique in the cytologic examination of the first CSF sample of patients clinically suspected of LMM.

\section{MATERIALS AND METHODS}

CSF obtained at the first lumbar puncture from patients clinically suspected of LMM was used both for cytology and interphase cytogenetics. The FISH procedure was essentially done as described before ${ }^{3}$; after an enzymatic pretreatment step using pepsin the biotinylated DNA probe for chromosome 1 (1q12, pUC 1.77; Cooke and Hindley ${ }^{4}$ ) was hybridized overnight. After hybridization, the slides were washed under stringent conditions avoiding minor bindings. The probe was detected using two layers of fluorescein-isothiocyanate conjugated to avidin coupled by a layer of biotinylated goat-anti-avidin. The slides were evaluated using the criteria described before. ${ }^{3}$ The results obtained with the FISH technique were compared with those of the cytologic evaluation of the Giemsa stained preparations. Also, the results of the FISH procedure were correlated to the cell number of CSF and to the type of primary tumor. LMM was diagnosed when malignant cells were demonstrated by cytology, or when malignant leptomeningeal infiltration was detected at autopsy.

\section{RESULTS}

The CSF of 45 patients was cytologically examined because of a clinical suspicion of LMM of the following malignancies: 15 breast carcinomas, 9 non-Hodgkin lymphomas, 5 small-cell lung carcinomas, 4 non-small-cell lung carcinomas, 4 acute lymphoblastic leukemia's, 3 adenocarcinomas of unknown origin, 2 renal cell carcinomas, 1 medulloblastoma, 1 dysgerminoma, and 1 anaplastic bladdercarcinoma. 
Table 1. Combined results of cytology and fluorescence in situ hybridization (FISH) in the first CSF sample of 45 patients clinically suspected of LMM.

\begin{tabular}{|l|l|r|}
\hline Result of cytology & Result of FISH & \\
\hline Malignant cells & NCA present & $17 / 27$ \\
\hline & NCA absent & $7 / 27$ \\
\hline & Not evaluable & $3 / 27$ \\
\hline Atypical cells & NCA present & $3 / 8$ \\
\hline & NCA absent & $5 / 8$ \\
\hline Normal cells & NCA present & $0 / 10$ \\
\hline & NCA absent & $10 / 10$ \\
\hline
\end{tabular}

Abbreviation: NCA: numerical chromosomal aberrations.

Eventually, LMM was diagnosed in thirty-four of these patients. Table 1 shows the results obtained by cytology and FISH of the first CSF sample.

The first cytologic examination of the forty-five samples classified ten cases as normal, twenty-seven as malignant $(79 \%)$, and eight as atypical. Forty-two of the forty-five samples could be evaluated by FISH. Three malignant samples were not evaluable because of interpretation difficulties due to lysis or absence of cells on the slides.

FISH detected only disomic cells in the ten samples of the patients with normal cytologic results, whereas in seventeen of the twenty-four evaluable malignant samples (71\%) NCA for chromosome 1 were detected in 5 to $28 \%$ of the nuclei. FISH clearly detected NCA in three of the eight samples with atypical cells at first cytological examination (38\%). In all three cases, malignant cells were cytologically demonstrated after repetitive lumbar punctures. So, in approximately one-third of the patients with atypical cells at first cytologic examination, multiple lumbar punctures could have been avoided.

Positive FISH results were found in 74\% (17 out of 23) of the solid tumors with proven LMM, and in $27 \%$ ( 3 out of 11 ) of the lymphoproliferative diseases with LMM. NCA were more often detected in malignant samples with high cell number (above 3 cells per $\mu \mathrm{L}$ ) than in those with low cell number ( $81 \%$ resp. $50 \%$ ). However, two of the three atypical samples with NCA detected by FISH had a low cell number.

The FISH results in the patients ultimately diagnosed as not having LMM showed no aberrant cells. Although the specificity of FISH was $100 \%$, the negative predictive value was only $50 \%$.

After repeated cytologic examination, five of the eight samples with atypical cells were classified as malignant, increasing the sensitivity of cytology to $94 \%$, but an extra twenty lumbar punctures in all had to be done for this. One more case with atypical cells could be 
classified as LMM at autopsy. The ten samples classified as normal at first cytologic examination remained normal even after three lumbar punctures. However, LMM was demonstrated at autopsy in one of these cases.

\section{DISCUSSION}

The detection of malignant cells in the CSF by conventional cytology is generally required to establish the diagnosis of LMM, although this approach is only moderately sensitive.' The aim of this study was to analyze the additional diagnostic value of FISH by detecting aneusomy for chromosome 1 in the cells present in the CSF of patients clinically suspected of having LMM to demonstrate malignancy, especially if the first cytologic examination was inconclusive. Although this chromosome generally detects aneusomy rather than being tumor specific, chromosome 1 is frequently involved in the carcinogenesis of solid tumors, and, to a lesser extent, during the progression of lymphoproliferative diseases. ${ }^{5,6}$ Moreover, aneusomy for chromosome 1 in cells present in the CSF was only detected in malignant samples. ${ }^{3}$ None of the cytologically normal samples displayed a NCA for chromosome 1 . All ten patients had two more lumbar punctures, which did not alter the first cytologic classification. One might argue that the finding of normal cytology combined with a normal FISH result in the first CSF sample is sufficient to exclude LMM. However, although the specificity of FISH was very good, a negative FISH result is not of additional diagnostic value, due to its low negative predictive value. Furthermore, LMM was demonstrated at autopsy in one patient with persistently negative cytology and normal FISH results. Possibly, the adherence of the malignant cells to the leptomeninges was that strongly that no cells were exfoliated into the CSF. ${ }^{7}$ In 71 percent of the samples classified as malignant at first cytology nuclei with NCA were detected by FISH. Although we were unable to classify all the cytologically malignant samples as aberrant, the sensitivity of FISH can be increased by using multiple centromeric DNA probes, or by using specific DNA probes in cases with known genetic aberration of the primary tumor. Besides, FISH is not of additional value for a diagnosis of LMM in the case of positive cytology.

Of greater clinical importance is the finding of NCA in three of the eight samples with atypical cells at first cytologic examination, which proved to be malignant after repeated lumbar punctures. If the FISH technique had been used as a diagnostic adjunct to the cytologic evaluation, extra lumbar punctures could have been avoided in about one-third of the clinically suspected patients with atypical cells in their CSF. Furthermore, the time delay before starting the treatment in this patient group could have been avoided, which might have influenced the clinical course, as this depends on early treatment.

Other cytogenetic techniques to classify atypical cells found in CSF have been studied before such as flow-cytometry (FCM), DNA single cell cytometry and the polymerase chain reaction (PCR) technique. ${ }^{8.9 .10}$ However, none of these techniques can be used on a routine basis, because either the specificity was too low or the method itself has shortcomings. For the PCR 
technique for example the cytogenetic aberration must be known, and FCM requires a large number of cells.

In conclusion, we have demonstrated an additional diagnostic value for the FISH technique in classifying cytologically atypical cells in the CSF of patients clinically suspected of LMM. NCA detected by the FISH method obviates repetitive lumbar punctures in approximately one-third of these patients, resulting in a more rapidly definitive diagnosis. This might influence the clinical course through an earlier start of treatment.

\section{REFERENCES}

1. Posner JB. Neurologic complications of cancer. Philadelphia: FA Davis Comp, 1995:143-171.

2. Cajulis RS, Yu GH, Gokaslan ST, Hidvegi DF. Modified interphase cytogenetics technique as an adjunct in the analysis of atypical cells in body fluids. Diagn Cytopathol 1997;16:331-335.

3. Van Oostenbrugge RJ, Hopman AHN, Lenders MH, et al. Detection of malignant cells in cerebrospinal fluid using fluorescence in situ hybridization.

J Neuropath Exp Neurol 1997;56:743-748.

4. Cooke HJ, Hindley J. Cloning of human satellite III DNA: different components are on different chromosomes. Nucleic Acids Res 1979;6:3177-3197.

5. Alers JC, Van Dekken H. Interphase cytogenetic analysis of solid tumors by non-isotopic DNA in situ hybridization. Prog Histochem Cytochem 1996;31(3):31-85.

6. Johansson B, Mertens F, Mitelman F. Cytogenetic evolution patterns of Non-Hodgkin's Lymphoma. Blood 1995;86:3905-3914.

7. Wasserstrom WR, Glass JP, Posner JB. Diagnosis and treatment of leptomeningeal metastases from solid tumors: Experience with 90 patients. Cancer 1982;49:759-772.

8. Cibas ES, Malkin MG, Posner JB, Melamed MR. Detection of DNA abnormalities by flow cytometry in cells from cerebrospinal fluid. Am J Clin Pathol 1987;88:570-577.

9. Biesterfeld S, Bernhard B, Bamborschke S, Böcking A. DNA single cell cytometry in lymphocytic pleiocytosis of the cerebrospinal fluid. Acta Neuropathol 1993;86:428-432.

10. Rhodes $\mathrm{CH}$, Glantz MJ, Glantz L, et al. A comparison of polymerase chain reaction examination of cerebrospinal fluid and conventional cytology in the diagnosis of lymphomatous meningitis. Cancer 1996;77:543-548. 


\section{CHAPTER 7}

INTERPHASE CYTOGENETICS INCREASES THE SENSITIVITY OF TREATMENT RESPONSE MONITORING IN PATIENTS WITH LEPTOMENINGEAL METASTASES

Adapted from:

RJ van Oostenbrugge, AHN Hopman, JW Arends, FCS Ramaekers and A Twijnstra. Treatment of leptomeningeal metastases evaluated by interphase cytogenetics. Submitted. 


\section{ABSTRACT}

Although cytologic examination of cerebrospinal fluid (CSF) is the main method to evaluate response to therapy for leptomeningeal metastases (LMM), the procedure's sensitivity decreases in the course of protracted therapy due to decreasing cell number and changes in cytomorphology. We studied whether this response can be monitored more accurately by detecting numerical chromosomal aberrations by means of the fluorescence in situ hybridization (FISH) technique.

Of seven patients treated for LMM, with a known numerical aberration for chromosome 1 in the malignant cells in the pretreatment CSF, up to 16 consecutive CSF samples were analyzed for cells with an aberrant chromosome 1 content. The results of routine cytology and the FISH procedure were compared, and were correlated with the neurological status.

Routine cytology detected malignancy in only 24 of the 76 samples, all of which were classified as chromosomally abnormal by the FISH procedure (except for two samples that could not be evaluated). Moreover, the FISH procedure demonstrated aneusomic cells in 32 additional samples, which could therefore be classified as malignant. Also, the FISH results correlated better with the neurological status, in that more malignant cells were detected in the CSF of neurologically deteriorating patients. Using the FISH method in addition to routine cytological screening thus led to a more accurate evaluation of response to treatment in the individual cases.

In conclusion, improved monitoring of response to therapy for LMM is achieved by the use of the FISH procedure in the cytodiagnosis of CSF. This may in future result in more efficient treatment protocols. 


\section{INTRODUCTION}

Metastatic spread to the leptomeninges is estimated to occur in up to $8 \%$ of patients with systemic cancer and is characterized by diffuse and often multifocal infiltration of the leptomeninges. ${ }^{1}$ Current treatment modalities include chemotherapeutic agents administered into the subarachnoid space. ${ }^{1,2}$ Evaluation of treatment response is difficult, despite the fact that several methods are currently available. Boogerd et al found the clinical neurological status to be a good predictor of the response to therapy. ${ }^{3}$ However, neurological improvement is generally hard to achieve due to irreversible damage of the nervous tissue by the tumor. Tumor response is usually assessed by sequential cytological examinations of the cerebrospinal fluid (CSF). ${ }^{2}$ However, this method loses much of its sensitivity in the course of protracted therapy, due to a decrease in cell number, cellular changes (like cell enlargement, cytoplasmic vacuolization, and multinucleation), and the presence of reactive ependymal cells in the CSF. ${ }^{4}$ Furthermore, Shapiro et al reported that malignant meningeal infiltration was detected at autopsy in all treated patients, even in patients with apparently normal cytology of CSF prior to death. ${ }^{5}$

Additional tests such as immunocytochemistry and biochemical tumor marker assays are considered to be of no additional value in evaluating the response to therapy in case of LMM, due to their lack of sensitivity. ${ }^{2}$ The few exceptions are carcinoembryonic antigen (CEA) in the case of LMM of solid tumors, and the soluble form of CD-27 in the CSF of patients with leukemic LMM, which have proved to be sensitive markers for response to therapy. ${ }^{6,7}$ The in situ hybridization technique is based on the targeted detection of numerical or structural chromosomal aberrations in the interphase nucleus by means of specific DNA probes. $^{8}$

The application of this method is therefore generally referred to as interphase cytogenetics. The usefulness of this technique in CSF cytodiagnosis has been demonstrated, showing that only malignant CSF samples contained cells with an increased copynumber for chromosome 1. ${ }^{9}$ It has already been demonstrated by flowcytometric studies that DNA aneuploidy is associated with malignancy, and that aneusomy for chromosome 1 is generally a good indicator of DNA aneuploidy. ${ }^{10,11}$ Because other studies have also detected an exclusive increase in the copynumber of chromosome 1 in (pre)malignant lesions and no aneusomy for chromosome 1 in normal tissue, it is assumed that cells with an increased copynumber truly represent malignant cells. ${ }^{12,13}$ An increase in the copynumber of chromosome 1 is usually accompanied by aberrations in other chromosomes. ${ }^{14,15}$

Recent studies have shown that interphase cytogenetics is more sensitive than routine cytology in detecting residual tumor cells present in bone marrow and recurrent bladder cancer in bladder irrigation specimens. ${ }^{16-18}$ The aim of the present study was to evaluate the diagnostic value of interphase cytogenetics for the assessment of persistent malignancy in the CSF during treatment of LMM. 


\section{MATERIALS AND METHODS}

Seven patients with LMM of systemic cancer diagnosed by the cytological detection of malignant cells in the CSF, and with a known numerical aberration for chromosome 1 detected by FISH in the cells of the pretreatment CSF, were included in this study. All patients were being treated intrathecally or intraventricularly with chemotherapeutic agents according to standard protocols. ${ }^{2,19}$ If three consecutive ventricular CSF samples were found to be cytologically normal, lumbar CSF was examined. Six ml of CSF, either ventricular or lumbar, were obtained before every consecutive bolus injection into the subarachnoid space and used for cytologic examination of Giemsa stained slides and for the FISH procedure.

To study a possible influence of chemotherapy on the development of numerical chromosomal aberrations, we evaluated the CSF of three additional patients who were also being treated for LMM but had shown no aberration for chromosome 1 in the cells from the pretreatment CSF.

\section{FISH protocol.}

After cytocentrifugation of the $70 \%$ ethanol fixed CSF samples onto poly-L-lysine coated glass slides, the preparations were proteolytically pretreated as described before. ${ }^{9,20}$ Pepsin from porcine stomach (2500-3500 units per mg. protein; Sigma, St. Louis, USA) was applied at a concentration of $100 \mu \mathrm{g} / \mathrm{ml}$. in $0.01 \mathrm{~N} \mathrm{HCl}$ for $20 \mathrm{~min}$. at $37^{\circ} \mathrm{C}$. Following pepsin digestion, the slides were rinsed for $5 \mathrm{~min}$. in $0.01 \mathrm{~N} \mathrm{HCl}$ at room temperature and subsequently dehydrated in an acidified ethanol series $(70 \%, 96 \%, 100 \%$ respectively). After dehydration, the slides were fixed in $1 \%$ paraformaldehyde in phosphate-buffered saline (PBS) for $5 \mathrm{~min}$. at room temperature, with five subsequently washes in PBS and five washes in bidistilled water. Thereafter, the slides were dehydrated in $70 \%, 96 \%$ and $100 \%$ ethanol. In situ hybridization was done essentially as described before. ${ }^{9,20}$ The biotinylated, centromeric probe for chromosome 1 (1q12, pUC 1.77; Cooke and Hindley ${ }^{21}$ ) was hybridized to its target DNA in a hybridization buffer containing $60 \%$ formamide, $2 \times \operatorname{SSC}(0.15 \mathrm{NaCl}, 15$ $\mathrm{mM}$ Na-citrate; $\mathrm{pH} 7.0$ ), $10 \%$ dextran sulphate, $0.2 \mathrm{mg} / \mathrm{ml}$ yeast tRNA, and $0.2 \mathrm{mg} / \mathrm{ml}$ herring sperm DNA under a coverslip, and denaturated at $70^{\circ} \mathrm{C}$ for $3 \mathrm{~min}$. on a heating plate. Hybridization was performed overnight in a moist chamber at $37^{\circ} \mathrm{C}$. Post-hybridization washes included $0.1 \times \mathrm{SSC}$ at $60^{\circ} \mathrm{C}$ for $5 \mathrm{~min}$., followed by washing twice in $4 \times \mathrm{SSC} /$ Tween $0.05 \%$ at room temperature for $5 \mathrm{~min}$.

The immunocytochemical detection of the biotynilated probe was achieved with fluoresceinisothiocyanate (FITC) conjugated avidin (Vector Laboratories, Burligame, USA) and subsequent amplification of the signal by incubation with biotinylated goat-anti-avidin (Vector Labs.) and avidin-FITC (Vector Labs.). The nuclei were stained with propidium iodide $0.5 \mu \mathrm{g} / \mathrm{ml}$ (PI; Sigma). 


\section{Slide evaluation.}

We applied the FISH evaluation criteria as described before in that (a) overlapping nuclei were excluded; (b) nuclear morphology should be preserved; (c) the nucleus should be PI-positive and exhibit a low auto-fluorescent background; and (d) FISH signals should be of homogeneous intensity. ${ }^{8}$

Samples were classified as disomic if all nuclei examined showed two FISH signals for chromosome 1 . They were classified as aneusomic if nuclei with more than two signals were observed.

A Leica-DMBRE microscope equipped with an appropriate filter set for FITC and PI was used for microscopy.

\section{RESUlts}

A total of 76 CSF samples (59 ventricular and 17 lumbar punctures) were obtained for routine cytological examination and for FISH studies from seven patients known with the following malignancies: non-Hodgkin lymphoma ( 3 cases), breast cancer ( 3 cases), and a malignancy of unknown primary (1 case). Table 1 provides an overview of cytology and FISH results of all samples taken together.

Table 1: Comparison of results of routine cytology and the FISH procedure in $76 \mathrm{CSF}$ samples of patients treated for leptomeningeal metastases.

\begin{tabular}{|l|lc|}
\hline \multirow{2}{*}{ Results of CSF cytology } & \multicolumn{2}{|l|}{ Results of FISH for chromosome I } \\
\hline Malignant $(\mathrm{n}=24)$ & - aneusomic (malignant) & 22 \\
& - disomic (normal) & - \\
& - not evaluable & 2 \\
\hline Suspicious $(\mathrm{n}=13)$ & - aneusomic (malignant) & 9 \\
& - disomic (normal) & 2 \\
& - not evaluable & 2 \\
\hline Normal $(\mathrm{n}=31)$ & - aneusomic (malignant) & 18 \\
& - disomic (normal) & 8 \\
& - not evaluable & 5 \\
\hline Not evaluable $(\mathrm{n}=8)$ & - aneusomic (malignant) & 5 \\
& - disomic (normal) & - \\
& - not evaluable & 3 \\
\hline
\end{tabular}

Abbreviation: FISH: fluorescence in situ hybridization. 
Cytology classified 24 CSF samples as malignant, 13 samples as suspicious, and 31 samples as normal. Eight samples were not evaluable by cytology due to the absence of cells or loss of cytomorphology. Using the FISH technique, 54 samples were found to contain aneusomic cells, which were therefore classified as malignant. Ten samples contained no aberrant cells, while 12 samples could not be evaluated. All the cytologically malignant samples could be classified as aneusomic by FISH, except for two preparations that were not evaluable by FISH due to a heterogeneous fluorescence signal distribution. FISH thus detected chromosomal aberrations in nine cytologically suspicious samples, in 18 cytologically normal samples and in five cytologically unevaluable samples, resulting in 32 additional diagnoses of malignancy. All of the 26 follow up samples of the three patients without chromosome 1 aneusomy in the pretreatment CSF were disomic, with the exception of two samples which showed sporadic aneusomic cells.

Table 2 (p. 75) summarizes the cytology and FISH results of the individual patients, and correlates these with the neurological status. A more accurate evaluation of response to intrathecal treatment was achieved by inclusion of FISH results in six of the seven patients, and these results correlated very well with the neurological status. Only in one patient (case 3) was no additional information obtained by the FISH method. In patient 6 , treatment was discontinued because of progressive neurological deterioration, although no malignant cells were detected by cytology. The FISH procedure detected aneusomic cells in most of these cytologically normal samples. In patient 7 , most of the samples were cytologically suspicious for malignancy, whereas FISH detected aneusomic cells in all of these. In four patients (cases 1, 2, 4 and 5), malignant cells were more frequently demonstrated by FISH than by routine cytology. In these patients, cytology of lumbar CSF demonstrated malignant cells despite a persistently cytologically normal ventricular CSF for five times, while in four of these instances aneusomic cells were still detected by FISH in these ventricular CSF samples . The FISH results correlated better with the clinical neurological status in that aneusomic cells were found more often in the CSF samples of clinically deteriorating patients than malignant cells were detected by cytological examination ( 20 versus 9 samples). Also, aneusomy was detected by FISH more frequently than malignant cells were found by cytology in the CSF samples during stable disease (30 versus 11 samples).

\section{Discussion}

A major problem in the current treatment of LMM patients is the inaccurate assessment of response to treatment. Tumor response is generally assessed by sequential cytologic screening of CSF, using the detection of malignant cells as the major criterion. ${ }^{2}$ However, cytology of CSF is only moderately sensitive during treatment, due to a decrease in cell number and changes in cell morphology. As a result, the correlation between the outcome of routine cytodiagnosis and treatment response is weak.

Because evaluation of treatment could not be improved by the application of immunocytochemical procedures or by assays for tumor markers, ${ }^{1,2}$ we analyzed the potential 
Table 2: Results of cytology and the fluorescence in situ hybridization technique in consecutive CSF samples of individual patients, combined with the neurological status.

\begin{tabular}{|c|c|c|c|c|c|c|c|c|c|c|c|c|c|c|c|c|c|}
\hline & & \multicolumn{16}{|c|}{ Number of CSF sample } \\
\hline $\begin{array}{l}\text { Patient and } \\
\text { primary } \\
\text { tumor }\end{array}$ & CSF no. & 1 & 2 & 3 & 4 & 5 & 6 & 7 & 8 & 9 & 10 & 11 & 12 & 13 & 14 & 15 & 16 \\
\hline $\begin{array}{l}\text { breast } \\
\text { cancer }\end{array}$ & $\begin{array}{l}\text { cytology } \\
\text { FISH } \\
\text { neurol }\end{array}$ & $\begin{array}{l}+ \\
+ \\
\text { impr }\end{array}$ & $\begin{array}{c}+ \\
+ \\
\text { impr }\end{array}$ & $\begin{array}{c}\text { NE } \\
+ \\
\text { impr }\end{array}$ & $\begin{array}{c}+ \\
+ \\
\text { impr }\end{array}$ & $\begin{array}{l}\mathrm{NE} \\
\mathrm{NE} \\
\text { Impr }\end{array}$ & $\begin{array}{c}- \\
\text { impr }\end{array}$ & $\begin{array}{c}- \\
\text { impr }\end{array}$ & $\begin{array}{c}- \\
\text { stabl }\end{array}$ & $\begin{array}{l} \pm \\
+ \\
\text { stabl }\end{array}$ & $\begin{array}{l}+ \\
+ \\
\text { stabl }\end{array}$ & det & $\begin{array}{c}- \\
+ \\
\text { det }\end{array}$ & det & $\begin{array}{c}- \\
+ \\
\operatorname{det}\end{array}$ & $\begin{array}{r}- \\
+ \\
\operatorname{det}\end{array}$ & $\begin{array}{l}- \\
\text { det } \\
\text { det }\end{array}$ \\
\hline $\begin{array}{l}\text { 2. } \\
\text { breast } \\
\text { cancer }\end{array}$ & $\begin{array}{l}\text { cytolegy } \\
\text { FISH } \\
\text { neurol }\end{array}$ & $\begin{array}{c}+ \\
+ \\
\text { stabl }\end{array}$ & $\begin{array}{c}+ \\
+ \\
\text { stabl }\end{array}$ & $\begin{array}{c}- \\
- \\
\text { stabl } \\
\end{array}$ & $\begin{array}{l}\mathrm{NE} \\
\mathrm{NE} \\
\text { stabl } \\
\end{array}$ & $\begin{array}{c} \pm \\
+ \\
\text { stabl }\end{array}$ & $\begin{array}{c}- \\
+ \\
\text { stabl }\end{array}$ & $\begin{array}{c}- \\
+ \\
\text { stabl } \\
\end{array}$ & $\begin{array}{l}\text { NE } \\
\text { stabl }\end{array}$ & $\begin{array}{c}+ \\
\text { stabl }\end{array}$ & $\begin{array}{c}- \\
+ \\
\text { stabl }\end{array}$ & $\begin{array}{c}- \\
+ \\
\text { stabl }\end{array}$ & $\begin{array}{c}\cdot \\
\text { NE } \\
\text { stabl }\end{array}$ & $\begin{array}{c}+ \\
+ \\
\text { stabl }\end{array}$ & $\begin{array}{c} \pm \\
\text { NE } \\
\text { stabl }\end{array}$ & $\begin{array}{c}\text { NE } \\
+ \\
\text { stabl }\end{array}$ & \\
\hline $\begin{array}{l}\text { 3. } \\
\text { breast } \\
\text { cancer }\end{array}$ & $\begin{array}{l}\text { cytology } \\
\text { FISH } \\
\text { neurol }\end{array}$ & $\begin{array}{c}+ \\
+ \\
\text { stabl }\end{array}$ & $\begin{array}{c}+ \\
+ \\
\text { stabl }\end{array}$ & $\begin{array}{c}+ \\
\text { NE } \\
\text { stabl }\end{array}$ & $\begin{array}{c}+ \\
+ \\
\text { stabl }\end{array}$ & $\begin{array}{c}+ \\
+ \\
\text { stabl }\end{array}$ & $\begin{array}{c}+ \\
+ \\
\text { stabl }\end{array}$ & $\begin{array}{l} \pm \\
\text { det }\end{array}$ & $\begin{array}{c}+ \\
+ \\
\operatorname{det}\end{array}$ & $\begin{array}{l}\text { NE } \\
+ \\
\text { det }\end{array}$ & $\begin{array}{l}+ \\
\text { NE } \\
\text { det }\end{array}$ & & & & & & \\
\hline N.H.L. & $\begin{array}{l}\text { cytology } \\
\text { FISH } \\
\text { neurol }\end{array}$ & $\begin{array}{c}+ \\
+ \\
\operatorname{det}\end{array}$ & $\begin{array}{l}+ \\
+ \\
\text { det }\end{array}$ & $\begin{array}{l}+ \\
+ \\
\text { det }\end{array}$ & $\begin{array}{l}+ \\
+ \\
\operatorname{det}\end{array}$ & $\begin{array}{l}+ \\
+ \\
\text { det }\end{array}$ & $\begin{array}{l}\text { NE } \\
+ \\
\operatorname{det}\end{array}$ & $\begin{array}{c}- \\
+ \\
\text { det }\end{array}$ & $\begin{array}{l}\text { NE } \\
+ \\
\text { det }\end{array}$ & $\begin{array}{c} \pm \\
\dot{\operatorname{det}}\end{array}$ & $\begin{array}{l}\text { NE } \\
\text { NE } \\
\operatorname{det}\end{array}$ & & & & & & \\
\hline $\begin{array}{l}5 . \\
\text { N.H.L. }\end{array}$ & $\begin{array}{l}\text { cytology } \\
\text { FISH } \\
\text { neurol }\end{array}$ & $\begin{array}{c} \pm \\
+ \\
\text { stabl } \\
\end{array}$ & $\begin{array}{c}- \\
+ \\
\text { stabl } \\
\end{array}$ & $\begin{array}{c}- \\
+ \\
\text { stabl } \\
\end{array}$ & $\begin{array}{c}- \\
+ \\
\text { stabl } \\
\end{array}$ & $\begin{array}{c} \pm \\
+ \\
\text { stabl }\end{array}$ & $\begin{array}{l}+ \\
+ \\
\text { stabl }\end{array}$ & $\begin{array}{l} \pm \\
\text { NE } \\
\text { stabl }\end{array}$ & $\begin{array}{c}- \\
+ \\
\text { stabl }\end{array}$ & $\begin{array}{c}- \\
+ \\
\text { stabl }\end{array}$ & $\begin{array}{c}- \\
+ \\
\text { stabl }\end{array}$ & $\begin{array}{c}- \\
\text { det } \\
\end{array}$ & det & $\begin{array}{l} \pm \\
+ \\
\operatorname{det}\end{array}$ & $\begin{array}{c}- \\
+ \\
\operatorname{det}\end{array}$ & $\begin{array}{c}- \\
\text { NE } \\
\text { det }\end{array}$ & \\
\hline 6. & $\begin{array}{l}\text { cytology } \\
\text { FISH } \\
\text { neurol }\end{array}$ & $\begin{array}{l}+ \\
+ \\
\text { det }\end{array}$ & $\begin{array}{l}+ \\
+ \\
\text { det }\end{array}$ & $\begin{array}{c}- \\
+ \\
\operatorname{det}\end{array}$ & $\begin{array}{l}- \\
\text { det }\end{array}$ & $\begin{array}{c}- \\
+ \\
\operatorname{det}\end{array}$ & $\begin{array}{c}- \\
+ \\
\operatorname{det}\end{array}$ & & & & & & & & & & \\
\hline $\begin{array}{l}7 . \\
\text { unknown } \\
\text { primary }\end{array}$ & $\begin{array}{l}\text { cytology } \\
\text { FISH } \\
\text { neurol }\end{array}$ & $\begin{array}{c}+ \\
+ \\
\text { stabl }\end{array}$ & $\begin{array}{c} \pm \\
+ \\
\text { stabl }\end{array}$ & $\begin{array}{c} \pm \\
+ \\
\text { stabl }\end{array}$ & $\begin{array}{c} \pm \\
+ \\
\text { stabl }\end{array}$ & $\begin{array}{c} \pm \\
+ \\
\text { stabl }\end{array}$ & & & & & & & & & & & \\
\hline
\end{tabular}

Cytology results: +: malignant; \pm : suspicious for malignancy; -: normal CSF; NE: not evaluable.

FISH results: +: aneusomy; -: disomy (normal); NE: not evaluable.

Neurological status: impr: improving; stabl: stable; det: deteriorating.

Abbreviations: NE: not evaluable; neurol: neurological status; N.H.L.: non-Hodgkin lymphoma. 
value of interphase cytogenetics in the evaluation of response to treatment in LMM patients. We assessed the chromosome 1 content in cells of sequential CSF samples obtained during treatment of seven patients known with a numerical aberration for chromosome 1 in cells of the pretreatment CSF. Although involvement of chromosome 1 during tumorogenesis is rather aspecific, it is a good marker for aneuploidy, as has been demonstrated for example in cases of bladder cancer and breast cancer. ${ }^{10,14}$ Furthermore, aneusomy of chromosome 1 has not been detected in non-malignant suspensions of different origin, so that it could be used as marker of (pre)malignancy. ${ }^{12,13,15}$ As for cells present in CSF, we have demonstrated earlier that aneusomy was only present in CSF samples with cytologically malignant cells and not in non-malignant CSF samples. ${ }^{9}$ Although aneusomic cells might develop infrequently during therapy (two of the 26 control samples sporadically contained aneusomic cells), this does not interfere with the evaluation of the response to therapy in patients with a known aberration of chromosome 1.

In all, FISH classified 54 samples as aneusomic, which were therefore regarded as malignant. In only 22 of these 54 samples could malignant cells be detected by means of routine cytology. The higher sensitivity of the FISH technique can be explained from its more objective assessment, ${ }^{8}$ because strict criteria were applied before cells were considered to be aneusomic, whereas cytology depends more on a subjective assessment of cytomorphologic features. $^{22}$

There are several reasons to take the FISH results in these samples as an indication of the presence of malignancy. First of all, in all samples with cytologically normal ventricular CSF but abnormal FISH results, the presence of malignant cells was demonstrated in the lumbar CSF by cytodiagnosis. Secondly, clinical deterioration despite normal CSF cytology but in the presence of aneusomy was seen in two of the patients. Thus, the FISH results correlated better with the clinical course.

Grossman et al stated that no correlation exists between neurological status and CSF cytology during treatment. ${ }^{23}$ Others, by contrast, found a good correlation between the CSF cytology results and clinical parameters, and recommended both criteria for response evaluation. 5,24 Boogerd et al found neurological status after the first 6 weeks of treatment to be a better predictor than the cytologic response at that time. ${ }^{3}$ Our results demonstrate that the correlation between cytology and the clinical course is weak, while the FISH results correlate better with the neurological status and course of the disease. It was especially in cases with deteriorating neurological status that more often abnormal CSF samples were detected by the FISH procedure than by routine cytology. In cases with stable neurological disease the clinical status alone is a poor predictor of response to therapy. Our results demonstrate that taking the FISH results into account enables one to discriminate between stable neurological disease due to response to therapy and apparent stabilization due to severely damaged neural tissue but without response to therapy.

Besides cytomorphological examination, monitoring of response to treatment has been assessed by the use of biochemical markers. Only serial measurements of CEA in the CSF has been found to function as useful marker in monitoring the response to therapy of LMM from solid tumors. ${ }^{6}$ Other markers such as lactate dehydrogenase, beta-glucoronidase, and 
beta-2-microglobulin could not be recommended as response criteria during treatment. ${ }^{25}$ Also, the application of immunocytochemistry using several monoclonal antibodies to detect malignant cells in the CSF samples of patients with LMM of solid tumors resulted in only a minor increase in diagnostic accuracy. ${ }^{26}$ However, by using an enzyme-linked immunosorbent assay, Kersten et al demonstrated a higher sensitivity of serial measurements of the soluble form of CD27 in the CSF of patients with LMM of certain hematologic malignancies as compared to routine cytology.

The question remains whether the FISH results would have influenced the treatment protocol had they been taken into account. In two patients with stable neurological disease and normal cytology of the ventricular CSF, but with an aberration detected by FISH and positive cytology of the lumbar CSF, an alternative drug would have been administered if the FISH results had guided the treatment. In another patient with stable neurological disease and persistently suspicious cytology, FISH found aneusomic cells in all samples, supporting the diagnosis of persistent LMM and thus providing an extra argument for changing the drug being used. Another patient showed clinical deterioration even though lumbar CSF cytology became apparently normal during therapy. However, all these cytologically normal samples contained aneusomic cells as detected by FISH. There are currently no clear guidelines in such cases. Zachariah et al have stated that other chemotherapeutic agents must be used whenever the neurological status deteriorates despite normal cytology. ${ }^{27}$ Other authors have used only CSF cytology as a response parameter, ${ }^{19,28}$ because a deterioration of neurological symptoms and signs could be the result of ongoing damage to the nervous tissue. The FISH procedure now offers the clinician an extra argument to change an ineffective therapy at an earlier stage in the course of treatment.

Furthermore, lumbar punctures could have been avoided in some patients. Because the sensitivity of CSF cytology decreases due to the decreasing number of cells in the course of treatment, ${ }^{4}$ a phenomenon which is especially obvious in the cytology of the ventricular $\mathrm{CSF}^{29}$ a reliable diagnosis can be made if the clearance of malignant cells from ventricular $\mathrm{CSF}$ during treatment is confirmed by cytologic examination of lumbar CSF. ${ }^{4} \mathrm{We}$ also found for five times in our series of patients malignant cells by lumbar cytology despite consecutively normal ventricular CSF cytology. In four of these five, an aberrance in chromosome 1 was still detectable in the ventricular CSF by the FISH technique, demonstrating its higher sensitivity compared to cytology.

In conclusion, the FISH technique is a sensitive test for detecting residual tumor cells in the CSF of patients during treatment for LMM. The FISH results correlate better with the clinical neurological status than the results of routine cytology. Response to therapy is therefore more accurately evaluated by the application of the FISH technique in conjunction with conventional cytology. This might result in an improvement of the treatment of patients with LMM.

\section{REFERENCES}

1. Posner JB. Neurologic complications of cancer. Philadelphia: FA Davis Comp, 1995:143-171. 
2. Chamberlain MC. Leptomeningeal metastases. In: Vecht $\mathrm{Ch}$ J, ed. Handbook of Clinical Neurology, Vol. 25 (69): Neuro-Oncology, Part III. Amsterdam: Elsevier Science BV, 1997:151-165.

3. Boogerd W, Hart AAM, Van der Sande JJ, Engelsman E. Meningeal carcinomatosis in breast cancer. Prognostic factors and influence of treatment. Cancer 1991;67:1685-1695.

4. Twijnstra A, Glass JP. Leptomeningeal metastasis from solid extracranial tumors. In: Twijnstra A, Keyser A, Ongerboer de Visser BW, eds. Neuro-Oncology. Amsterdam: Elsevier Science B.V., 1993:257-279.

5. Shapiro WR, Posner JB, Ushio Y, Chernik NL, Young DF. Treatment of meningeal neoplasms. Cancer Treat Rep 1977;61:733-743.

6. Yap BS, Yap HY, Fritsche HA, Blumenschein G, Bodey GP. CSF carcinoembryonic antigen in meningeal carcinomatosis from breast cancer. JAMA 1980;244:1601-1603.

7. Kersten MJ, Evers LM, Dellemijn PLI, et al. Elevation of cerebrospinal fluid soluble CD27 levels in patients with meningeal localization of lymphoid malignancies.

Blood 1996;87:1985-1989.

8. Hopman AHN, Voorter CEM, Ramaekers FCS. Detection of genomic changes in cancer by in situ hybridization. Mol Biol Reports 1994;19:31-44.

9. Van Oostenbrugge RJ, Hopman AHN, Lenders MH, et al. Detection of malignant cells in cerebrospinal fluid using fluorescence in situ hybridization. J Neuropath Exp Neurol 1997;56:743-748.

10. Hopman AHN, Moesker O, Smeets AWGB, Pauwels RPE, Vooijs GP, Ramaekers FCS. Numerical chromosome 1, 7,9, and 11 aberrations in bladder cancer detected by in situ hybridization. Cancer Res 1991;51:644-651.

11. Shackney SE, Singh SG, Yakulis R, et al. Aneuploidy in breast cancer: a fluorescence in situ hybridization study. Cytometry 1995;22:282-291.

12. Segers $\mathrm{P}$, Haesen $\mathrm{S}$, Castelain $\mathrm{P}$, et al. Study of numerical aberrations of chromosome 1 by fluorecent in situ hybridization and DNA content by densitometric analysis on (pre) malignant cervical lesions. Histochem J 1995;27:24-34.

13. Bulten J, Poddighe PJ, Robben JCM, Gemmink JH, De Wilde PCM, Hanselaar AGJM. Interphase cytogenetic analysis of cervical intraepithelial neoplasia.

Am J Pathol 1998;152:495-503.

14. Ichikawa D, Hashimoto N, Hoshima M, et al. Analysis of numerical aberrations in specific chromosomes by fluorescent in situ hybridization as a diagnostic tool in breast cancer. Cancer 1996;77:2064-2069.

15. Veltman JA, Hopman AHN, Bot FJ, Ramaekers FCS, Manni JJ. Detection of chromosomal aberrations in cytologic brush specimens from head and neck squamous cell carcinoma. Cancer 1997;81:309-314.

16. Zhao L, Kantarjian HM, Van Oort J, Cork A, Trujillo JM, Liang JC. Detection of residual proliferating leukemic cells by fluorescence in situ hybridization in CML patients in complete remission after interferon treatment. Leukemia 1993;7:168-171.

17. Arkesteijn GJA, Erpelinck SLA, Martens ACM, Hagemeijer A, Hagenbeek A. The use of FISH with chromosome-specific repetitive DNA probes for the follow-up of leukemia patients. Cancer Genet Cytogenet 1996;88:69-75.

18. Wheeless LL, Reeder JE, Han R, et al. Bladder irrigation specimens assayed by fluorescence in situ hybridization to interphase nuclei. Cytometry 1994;17:319-326. 
19. Ongerboer de Visser BW, Somers R, Nooyen WH, Van Heerde P, Hart AAN, McVie JG. Intraventricular methotrexate therapy of leptomeningeal metastasis from breast cancer. Neurology 1983;33:1565-1572.

20. Hopman AHN, Poddighe P, Moesker O, Ramaekers FCS. Interphase cytogenetics: an approach to the detection of genetic aberrations in tumours. In: Herrington CS, McGee JO'D, eds. Diagnostic molecular pathology. A practical approach, vol. 1. Oxford: IRL Press, 1992:141-161.

21. Cooke HJ, Hindley J. Cloning of human satellite III DNA: different components are on different chromosomes. Nucleic Acids Res 1979;6:3177-3197.

22. Andrews JM, Schumann GB. Neurocytopathology. Baltimore: Williams and Wilkins, 1992:52-64.

23. Grossman SA, Finkelstein DM, Ruckdeschel JC, Trump DL, Moynihan T, Ettinger DS. Randomized prospective comparison of intraventricular methotrexate and thiotepa in patients with previously untreated neoplastic meningitis. J Clin Oncol 1993;11:561-569.

24. Wasserstrom WR, Glass JP, Posner JB. Diagnosis and treatment of leptomeningeal metastases from solid tumors: experience with 90 patients. Cancer 1982;49:759-772.

25. Van Zanten AP, Twijnstra A, Ongerboer de Visser BW, Van Heerde P, Hart AAM, Nooyen WJ. Cerebrospinal fluid tumour markers in patients treated for meningeal malignancy. JNNP 1991;54:119-123.

26. Boogerd W, Vroom ThM, Van Heerde P, Brutel de la Rivière G, Peterse JL, Van der Sande JJ. CSF cytology versus immunocytochemistry in meningeal carcinomatosis. JNNP 1988;51:142-145.

27. Zachariah B, Zachariah SB, Varghese R, Balducci L. Carcinomatous meningitis: clinical manifestations and management. Int J Clin Pharm Ther 1995;33:7-12.

28. Siegal T, Lossos A, Pfeffer MR. Leptomeningeal metastases: analysis of 31 patients with sustained off-therapy response following combined-modality therapy. Neurology 1994;44:1463-1469.

29. Rogers LR, Duchesneau PM, Nunez C, et al. Comparison of cisternal and lumbar CSF examination in leptomeningeal metastases. Neurology 1992;42:1239-1241. 



\section{CHAPTER 8}

SUMMARY AND CONCLUSIONS 


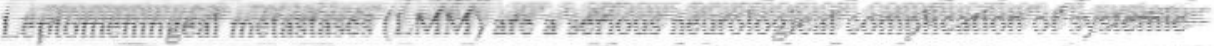

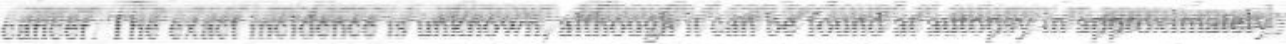

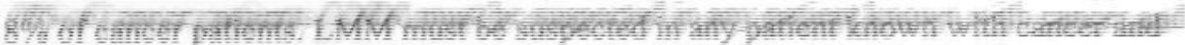

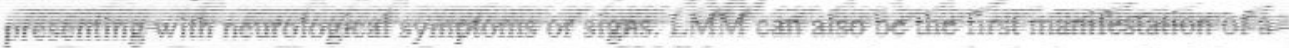

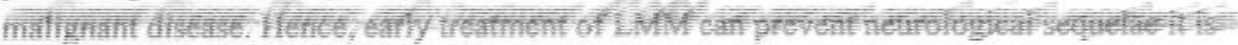

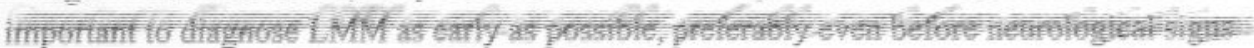

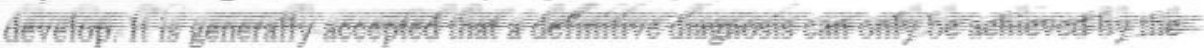

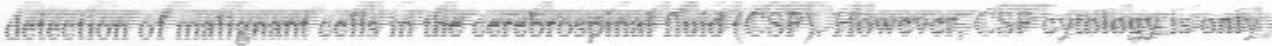

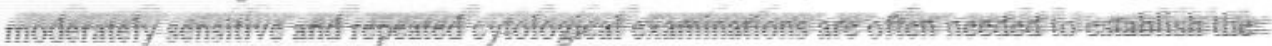

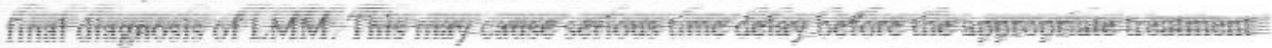

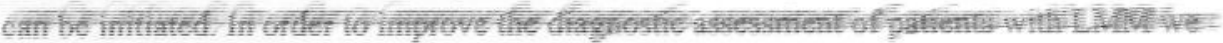

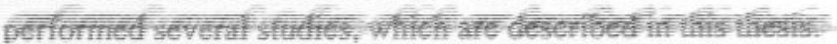

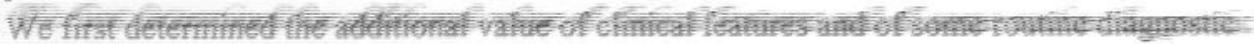

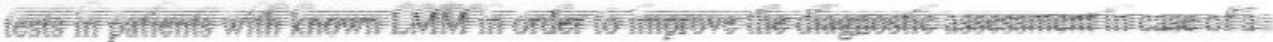

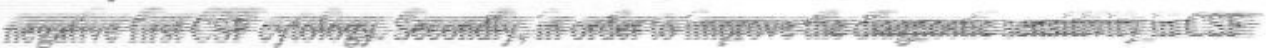

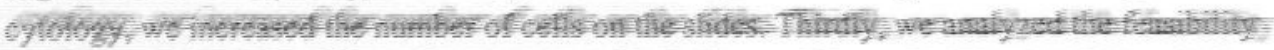

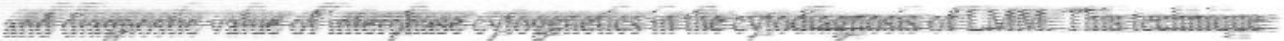

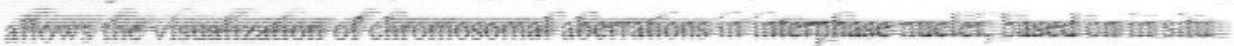
hybridization with labeled DNA probes. Although interphase cytogenetics has been performed on several body fluids such as urine, blood and pleural fluid, it had not been used before on CSF.

Once the diagnosis of LMM has been established, treatment with chemotherapy or radiation can be initiated. Because of the potential risks of intrathecal chemotherapy, and for an adequate treatment protocol, the response to treatment must be monitored accurately. Currently, monitoring of response to therapy is achieved by consecutive CSF cytodiagnoses. However, the sensitivity of CSF cytology decreases during (prolonged) therapy due to a decrease in the cell numbers and the occurrence of reactive, atypical cells. Other parameters like the neurological condition or immunological tumor markers are also weak predictors of response. Therefore, the ISH technique was applied as an alternative method to improve the follow up of therapy.

CHAPTER 1 reviews the literature on clinical features of LMM and the sensitivity of the currently used diagnostic tests. Although the studies reviewed were rather heterogeneous, it can be concluded that CSF cytology is still the single most important diagnostic test for LMM at this moment, although its sensitivity is only moderate.

CHAPTER 2 reports on a study of the presenting neurological features and the value of routine diagnostic procedures related to the histological type of the primary malignancy, involving 45 patients with proven LMM. It was found that patients have a different clinical presentation depending on the histology of the primary tumor. Most patients with LMM of hematological malignancies showed cranial nerve dysfunction at the time of presentation, whereas patients with LMM of solid tumors mostly presented with spinal and radicular symptoms and signs. 
This difference may be explained by different routes of dissemination from the different primary malignancies to the leptomeninges. LMM of solid tumors virtually always present with adjacent bone marrow metastases, suggesting the propagation of malignant cells from these metastases to the leptomeninges.

By contrast, hematological LMM develop via hematogenous spreading to the leptomeninges, preferentially at the base of the skull, due to the well developed blood supply in this region. Further studies are needed, however, to increase the knowledge on the pathogenesis of LMM. The differences in the neurological symptoms at the time of presentation are not useful for a diagnosis of LMM. However, it could be demonstrated that the majority of these patients presented with multifocal neurological symptoms. In the case of negative cytological results, these clinical features, combined with increased levels of total CSF protein, can be used as a diagnostic criterion. A diagnosis could also be established when increased total CSF protein was combined with abnormal neuro-imaging findings. However, both alternatives are not useful in evaluating response to therapy.

Although it is generally agreed that multiple lumbar punctures should be performed in the case of inconclusive CSF cytodiagnosis in a patient clinically suspected of LMM, we demonstrated that repeated lumbar punctures increase the sensitivity of cytology mainly in patients with hematological malignant disease.

CHAPTER 3 describes the optimalization of cytospin preparations used during cytology of CSF. Poly-L-lysine coated glass-slides were applied in an attempt to increase the fraction of cells adhering to the slides. Although increased numbers of cells did indeed become attached to the slides, this fraction was not enough to increase the sensitivity of cytodiagnosis.

These findings are in contrast with the positive results found for urine samples and buccal smears, in which a poly-L-lysine coating led to a much greater increase in the number of cells on slides, subsequently increasing the sensitivity of the cytodiagnosis. One explanation for this difference might be the low levels of protein in the latter specimens, while the high protein levels of the CSF might mask the poly-L-lysine residue and thus resulting in a lower affinity for the cells.

CHAPTER 4 demonstrates the feasibility of the in situ hybridization (ISH) technique on cells from CSF. We found that some steps in the ISH protocol were crucial for obtaining evaluable ISH signals due to the nature and biological variation of the material studied. First of all, loss of cell morphology was a serious problem, due to the fragility of cells in CSF. This problem can be overcome by direct fixation of the CSF sample in $70 \%$ ethanol after lumbar puncture. Secondly, a tuned proteolytic pretreatment step is needed because of the high protein content of CSF. Thirdly, the time of DNA denaturation has to be short, because of the fragility of the CSF cells.

In applying the ISH method to CSF, aneusomic cells were only detected in cytologically malignant samples, whereas only disomic cells were detected in reactive CSF samples from patients with infectious neurological diseases. A DNA probe for the centromeric region of chromosome 1 was chosen for these studies. This probe is not tumor-specific, but it can be 
used to screen for general aneuploidy. However, general aneuploidy develops mainly in solid tumors and is only sporadically found in hematological tumors. For these cases the use of more tumor-specific probes for the detection of specific genetic alterations is likely to provide more relevant results.

CHAPTER 5 discusses a comparison between the numerical content of chromosomes 1, 7, and 10 in malignant cells in the CSF and their corresponding leptomeningeal metastases and primary tumors. It is generally accepted that malignant cells in the CSF originate from leptomeningeal infiltration, because of morphological similarities. Before the ISH method can be used as an adequate diagnostic test in patients suspected of LMM, it is a prerequisite for a proper diagnosis that the same genotypic constitution can be detected in tumor cells from the subsequent sites. Furthermore, before the known chromosomal aberration in the CSF cells can be used in the evaluation of a response to therapy, it is important to know that these cells represent the malignant infiltration of the leptomeninges. The present study demonstrates that the genetic contents in CSF cells, leptomeningeal infiltration and primary tumor are identical with respect to the copynumbers for chromosomes 1,7 , and 10 . This finding supports the assumption that cells present in the CSF are indeed shed from the LMM and that the chromosomal aberration detected in these cells represents that of the LMM.

The additional diagnostic value of the ISH method using a chromosome 1 probe in patients clinically suspected of LMM is described in CHAPTER 6. By detecting aneusomic cells in the CSF we were able to improve the diagnosis in about a third of the patients with atypical cells at first cytological examination. Unfortunately, a negative ISH result (no aneusomy detected) can not be used to exclude the presence of malignancy. In addition, a few malignant samples could not be classified as genetically aberrant. Both problems can be overcome by using either a panel of centromeric DNA probes to different chromosomes, which will increase the sensitivity, or by using tumor-specific probes to increase the specificity. Ideally, the primary tumor should be analyzed first to determine the presence and nature of genetic alterations, using sophisticated approaches, such as the comparative genomic hybridization technique. In the case of hematological malignant diseases, classical karyotyping could also be applied. Once identified, the specific genetic hallmark can be used to demonstrate cells with the same aberration in the CSF. A negative ISH result will then provide additional information, strongly indicating normal CSF.

In CHAPTER 7 it is demonstrated that the ISH technique in adjunct to CSF cytology provides a method for more accurate monitoring of response to therapy. The number of samples that could be classified as malignant was more than doubled relative to those found in the cytological examination. As a result, the evaluation of therapy in individual patients by analysis of subsequent CSF samples was more accurate in six of the seven patients. No other method has shown such an improvement in monitoring LMM treatment, although it has recently been reported that serial measurements of carcinoembryonic antigen in the case of LMM of solid tumors was also more accurate than consecutive CSF cytology. However, as 
has been found for almost any tumor marker, the normal values partly overlapped the values of abnormal cases.

A larger study is needed to confirm our results and to analyze whether the outcome of LMM patients can be improved by this method.

IN CONCLUSION, it can be stated that interphase cytogenetics by means of the in situ hybridization technique is a feasible and valuable adjunct to routine CSF cytology in the cytodiagnosis of LMM. Furthermore, the response to therapy for LMM is monitored more accurately with the help of this method, which may improve the results of treatment. The use of the ISH technique with more tumor-specific probes has therefore the potential of becoming an important diagnostic test in the assessment of patients with LMM. 

SAMENVATTING

INTERPHASE CYTOGENETICA IN DE CYTOLOGISCHE DIAGNOSTIEK VAN LEPTOMENINGEALE METASTASEN. 
Leptomeningeale metastasen (LMM) vormen een ernstige neurologische complicatie bij kanker. Hoewel exacte gegevens over de incidentie ontbreken, worden bij ongeveer $8 \%$ van de geobduceerde patiënten met kanker LMM gevonden. Bij iedere patiënt met kanker en neurologische klachten of verschijnselen moet men bedacht zijn op LMM. Echter, LMM kunnen ook de eerste manifestatie van een maligne aandoening zijn. Aangezien een tijdige behandeling neurologische verschijnselen kan voorkomen of verminderen, is het belangrijk om de diagnose LMM zo vroeg mogelijk te stellen en bij voorkeur vóór het ontstaan van neurologische uitvalsverschijnselen.

De definitieve diagnose wordt gesteld door het aantonen van maligne cellen in de liquor cerebrospinalis (liquor) met behulp van cytologisch onderzoek. Echter, de sensitiviteit van deze methode is matig en meerdere liquor onderzoeken zijn vaak nodig om de diagnose met zekerheid te kunnen stellen waardoor de behandeling vertraging kan oplopen. Ter verbetering van de diagnostiek van LMM werden door ons verscheidene studies verricht welke beschreven worden in dit proefschrift.

Wij bepaalden eerst de aanvullende waarde van klinische kenmerken en van enkele routine diagnostische tests bij patiënten met LMM met als doel de diagnose te kunnen stellen in geval van een eerste negatief cytologisch onderzoek. Ten tweede, om de diagnostische sensitiviteit van liquorcytologie te verbeteren, werd een methode onderzocht ter verhoging van het aantal cellen op de objectglaasjes voor cytologisch onderzoek. Hierna onderzochten we de mogelijkheid en de additionele waarde van interphase cytogenetica als diagnosticum van LMM. Met interphase cytogenetica kunnen chromosomale afwijkingen worden gevisualiseerd in interphase (niet-delende) celkernen door in situ hybridisatie met gelabelde DNA probes. Deze methode werd reeds toegepast op verschillende lichaamsvloeistoffen zoals urine, pleuravocht en bloed, maar nog niet eerder op liquor cerebrospinalis.

$\mathrm{Na}$ het stellen van de diagnose LMM, kan met de chemo- of radiotherapeutische behandeling worden gestart. Gezien de toxiciteit van de intra-thecale chemotherapie, en voor een adequate behandeling, is het van belang om de respons op deze therapie zo nauwkeurig mogelijk te evalueren. Tot nu toe wordt dit gedaan door het aantonen van maligne cellen in opeenvolgende liquores. Echter, ten gevolge van een afname in het aantal cellen tijdens de therapie en het ontstaan van atypische cellen door de therapie, vermindert de sensitiviteit van liquorcytologie. Andere parameters zoals de klinisch neurologische toestand of de aanwezigheid van immunologische tumor merkstoffen in de liquor hebben eveneens een matige voorspellende waarde. Om deze reden werd de in situ hybridisatie techniek toegepast als een alternatief ter verbetering van het evalueren van chemotherapie.

In HOOFDSTUK 1 wordt een literatuur overzicht gegeven van de klinische kenmerken van LMM en de sensitiviteit van de meest gebruikelijke diagnostische tests. Hoewel deze studies heterogeen zijn, kon uit deze literatuur geconcludeerd worden dat de liquorcytologie, ondanks de matige sensitiviteit, nog steeds het belangrijkste diagnosticum (gouden-standaard) voor LMM is. 
In HOOFDSTUK 2 worden de neurologische kenmerken bij presentatie en de waarde van routine diagnostische procedures bij vijfenveertig patiënten met bewezen LMM bestudeerd en gerelateerd aan het histologische type van de primaire maligniteit. Er was een duidelijk verschil in klinische presentatie van de twee verschillende typen LMM. Patiënten met LMM van een hematologische maligniteit toonden meestal uitval van één of meerdere hersenzenuwen, terwijl patiënten met LMM van een solide tumor zich meestal presenteerden met spinale of radiculaire verschijnselen. Echter, voor het stellen van de diagnose zijn verschillen in klinisch neurologische kenmerken bij presentatie niet bruikbaar.

Wel kon worden aangetoond dat de meerderheid van de patiënten zich presenteerden met multifocale symptomen, hetgeen in combinatie met een verhoogd eiwit in de liquor, gebruikt kan worden als diagnostisch criterium in geval van een negatief cytologisch onderzoek. De diagnose kon eveneens gesteld worden indien een verhoogd totaal eiwit in de liquor gelijktijdig aanwezig was met afwijkende neuroradiologische bevindingen.

Hoewel in het algemeen extra lumbaal puncties worden verricht in geval van negatieve liquorcytologie bij een patiënt die op klinische gronden verdacht wordt van LMM, toonden wij aan dat vooral bij patiënten met een maligne hematologische aandoening herhaalde lumbaal puncties de sensitiviteit van liquorcytologie verhoogde.

HOOFDSTUK 3 beschrijft het optimaliseren van cytospin-preparaten, welke gebruikt worden voor de cytologische diagnostiek van liquor. Ter verhoging van het aantal cellen die zich hechten aan de objectglaasjes werd een poly-L-lysine coating op deze glaasjes aangebracht. Van vijftig patiënten werd de verkregen liquor verdeeld en verwerkt met de cytospinmethode met gebruik van gewone en poly-L-lysine gecoate objectglaasjes. Ondanks een hoger celaantal op de gecoate glaasjes, was de toename onvoldoende om de sensitiviteit van de cytodiagnostiek van liquor te verbeteren.

In HOOFDSTUK 4 demonstreren we de mogelijkheid om de in situ hybridisatie (ISH) techniek toe te passen op cellen in de liquor. Hiertoe werd de liquor van tien patiënten met een infectieuze, neurologische aandoening en de cytologisch bewezen maligne liquor van tweeëntwintig patiënten met LMM onderzocht met de ISH methode met een chromosoom 1 specifieke probe. Met de ISH methode werden aneusome cellen alleen gevonden in de cytologisch bewezen maligne liquores, terwijl in de liquores van patiënten met een infectieuze neurologische ziekte alleen disome cellen werden aangetoond. Wel bleek dat -door de aard van het bestudeerde materiaal en de biologische variatie hierinsommige stappen in het ISH protocol van cruciaal belang waren voor het verkrijgen van evalueerbare ISH-signalen. Ten eerste: het verlies van celmorfologie door de fragiliteit van de liquorcellen bleek een serieus probleem. Dit probleem kon voorkomen worden door direct na de lumbaal punctie de liquor te fixeren in $70 \%$ ethanol. Ten tweede: door het hoge eiwitgehalte in de liquor was een nauwgezette proteolyse tijdens de voorbehandeling noodzakelijk. Ten derde: de duur van de DNA denaturatie diende kort te zijn, dit wederom vanwege de fragiliteit van de liquorcellen. 
In HOOFDSTUK 5 wordt het aantal kopieën van de chromosomen 1, 7, en 10 van de cellen in de liquor vergeleken met de overeenkomstige leptomeningeale infiltratie en de primaire tumor. Op basis van de morfologische overeenkomst wordt aangenomen dat de maligne cellen in de liquor afkomstig zijn van de leptomeningeale metastase. Alvorens de ISH methode gebruikt kan worden als een adequate diagnostische test bij patiënten die op klinische gronden verdacht worden van LMM, is het een vereiste dat in tumorcellen op de verschillende anatomische locaties dezelfde genotypische afwijkingen worden aangetoond. Verder is het van belang om aan te tonen dat deze liquorcellen representatief zijn voor de maligne infiltratie van de hersenvliezen, alvorens een gekarakteriseerde chromosomale afwijking in de liquorcellen gebruikt kan worden als parameter ter evaluatie van een respons op behandeling. In deze studie werd aangetoond dat het genotypische profiel in liquorcellen, leptomeningeale infiltratie en in primaire tumor inderdaad identiek was voor het aantal kopieën van de chromosomen 1 , 7, en 10.

In HOOFDSTUK 6 beschrijven we de additionele diagnostische waarde van de ISH methode met toepassing van een chromosoom 1 specifieke probe bij vijfenveertig patiënten die op klinische gronden verdacht werden van LMM. Hiertoe werden de resultaten van het eerste cytologisch onderzoek vergeleken met de resultaten van de ISH methode. Met cytologisch onderzoek werden tien liquores als normaal, zevenentwintig als maligne en acht als atypisch geclassificeerd. Met de ISH methode werden slechts disome cellen gevonden in de normale liquores, terwijl $71 \%$ van de evalueerbare maligne liquores een numerieke afwijking voor chromosoom 1 vertoonden. Daarnaast was het mogelijk om met behulp van het detecteren van aneusome cellen de diagnostiek te verbeteren in ongeveer een-derde van de patiënten met atypische cellen bij het eerste cytologisch onderzoek van de liquor. Een negatief ISH resultaat (geen aneusomie aangetoond) sloot echter de aanwezigheid van tumorcellen niet uit.

In HOOFDSTUK 7 wordt aangetoond dat de ISH techniek tezamen met de liquorcytologie leidt tot een accuratere evaluatie van een respons op therapie. Van zeven patiënten, die behandeld werden voor LMM, was bekend dat de maligne cellen in de liquor een numerieke afwijking voor chromosoom 1 hadden. Iedere liquor, die verkregen werd voor het toedienen van de intrathecale chemotherapie, werd cytologisch en met de ISH methode onderzocht. Hierdoor konden ongeveer anderhalf keer zo veel liquores als afwijkend worden geclassificeerd dan met cytologisch onderzoek alleen. Het evalueren van de therapie werd hierdoor accurater bij zes van de zeven patiënten. Door geen enkele methode kon tot nu toe een dergelijke verbetering van de evaluatie van de therapie van LMM worden aangetoond. Deze resultaten dienen te worden bevestigd in een grotere studie, waarin ook geanalyseerd zal moeten worden of de prognose van patiënten met LMM verbetert als de therapie wordt geëvalueerd met behulp van de ISH techniek.

CONCLUDEREND kunnen we stellen dat interphase cytogenetica met behulp van in situ hybridisatie toepasbaar is op cellen in de liquor en een waardevolle diagnostische test is in aanvulling op routine cytologisch onderzoek voor de diagnostiek van leptomeningeale 
metastasen. Ook kan de evaluatie van therapie voor leptomeningeale metastasen worden geoptimaliseerd door het gebruik van deze methode, hetgeen de behandelingsresultaten zou kunnen verbeteren. Het gebruik van de in situ hybridisatie techniek met tumor-specifieke probes kan een belangrijke diagnostische test worden voor patiënten met leptomeningeale metastasen. 


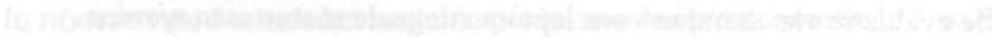

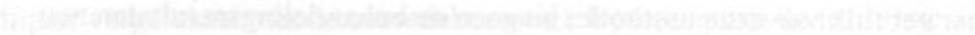




\section{DANKWOORD}

Het verschijnen van dit proefschrift geeft me de gelegenheid om een ieder die heeft bijgedragen in de totstandkoming ervan te bedanken. Zonder deze hulp had dit boekje er nu niet gelegen. Een aantal mensen wil ik met name bedanken voor hun belangrijke bijdrage:

Prof. dr. J. Troost, beste Jaap, het is een voorrecht om door jou op te worden geleid tot neuroloog. Bedankt voor de mogelijkheden en ruimte die je me bood, zowel gedurende mijn opleiding als voor dit onderzoek.

Prof. dr. F.C.S. Ramaekers, beste Frans, dank voor de wijze waarop je de manuscripten becommentarieerde. Het was een waar genoegen om hierna het manuscript in de "liquorclub" te bediscussiëren.

Dr. A. Twijnstra, beste Albert, zonder jou zou dit boekje er nooit zijn geweest! Eind 1994 polste je me, nadat je me eerst op inspirerende wijze enthousiast had gemaakt voor de neuro-oncologie, voor dit onderzoek. Het was het begin van een uiterst leerzame en boeiende periode. Door je optimisme en geloof in dit onderzoek, en de voortdurende stimulerende impulsen is het geworden tot wat het nu is. Ik hoop dat het afsluiten van deze periode het begin is van een langdurige en even plezierige samenwerking.

Dr. A.H.N. Hopman, beste Ton, in het begin van onze samenwerking moet je toch wel eens gedacht hebben "waar bén ik aan begonnen" (zeker toen chromosomen voor bacteriën werden aangezien....). Het jaar op het FISH-lab was dankzij je begeleiding een groot succes. Voor het afronden van de "FISH-studies" was je perfectionisme en kennis van interphase cytogenetica van onvervangbare waarde. And now, it is time to skate.....!

Prof. dr. J.W. Arends, beste Jan Willem, dank voor je hulp en adviezen op cytologisch gebied. Ik hoop dat de samenwerking in de toekomst verder kan worden uitgebouwd.

De medewerkers van de vakgroep Moleculaire Celbiologie \& Genetica en die van het FISH-lab in het bijzonder bedank ik voor hun gastvrijheid en belangstelling. Zonder iemand tekort te willen doen wil ik met name mijn kamergenoten Joris Veltman en Manon van Engeland bedanken voor de geboden hulp en gezelligheid. Tevens wil ik Marie-Hélène Lenders en Monique Ummelen bedanken voor hun geduld om mij enigszins "lab-veilig" te maken en voor de vele verrichte hand- en spandiensten.

De analisten van het cytologisch laboratorium dank ik voor de geboden hulp in het verzamelen van de liquores.

Dr. J.S.H. Vles, beste Hans, zowel in de kliniek als in wetenschappelijk onderzoek is het goed bouwen op een stevig fundament. Dank!

De Nederlandse Kankerbestrijding dank ik voor de financiële steun waardoor het mogelijk was om gedurende één jaar op het FISH-lab te werken aan dit onderzoek.

Mijn ouders, lieve pa en ma, bedankt voor de wijze waarop jullie me stimuleerden mijn eigen weg te kiezen, wetende dat ik altijd op jullie onvoorwaardelijke steun kon rekenen.

En tot slot, degene die anders bij mij altijd op één komt. Lieve Sonja, zonder jou had het misschien allemaal wat sneller gekund, maar het had dan zeker veel langer geleken! 



\section{CURRICULUM VITAE}

De schrijver van dit proefschrift werd geboren op 27 december 1965 te Havelte. Na behalen van het diploma Atheneum aan het Nassau College te Heerenveen in 1984, begon hij aan de Rijksuniversiteit Limburg (nu: Universiteit Maastricht) met de studie Geneeskunde.

Het doctoraal diploma werd cum laude behaald in augustus 1988. Tijdens deze studie was hij als student-assistent werkzaam bij de vakgroep Neurologie (Dr. J.S.H. Vles). In oktober 1990 werd het artsexamen behaald, waarna de militaire dienstplicht vervuld werd bij de $13^{\mathrm{de}}$ Brigade Geneeskundige Compagnie te Oirschot. In mei 1992 kwam hij in dienst van het Academisch Ziekenhuis Maastricht als assistent Neurologie, eerst als AGNIO en later in opleiding (opl. Prof. dr. J. Troost). In december 1994 werd onder begeleiding van Dr. A. Twijnstra gestart met dit onderzoek. Gedurende 1 jaar (april 1997-1998) was hij voor dit onderzoek werkzaam op het in situ hybridisatie laboratorium (Dr. A.H.N. Hopman) van de vakgroep Moleculaire Celbiologie \& Genetica (Prof. dr. F.C.S. Ramaekers), hetgeen mogelijk gemaakt werd door een beurs van de Nederlandse Kankerbestijding. In juli 2000 hoopt hij de opleiding tot neuroloog af te ronden. 



\section{PUBLICATIONS}

Van Oostenbrugge RJ, Twijnstra A.

Presenting features and value of diagnostic procedures in leptomeningeal metastases.

Neurology (in press).

Van Oostenbrugge RJ, Herpers MJ, De Kruijk JR.

Spinal cord compression caused by unusual location and extension of ossified ligamenta flava in a Caucasian male. A case report and literature review.

Spine 1999;24:486-488.

Van Oostenbrugge RJ, Hopman AHN, Arends JW, Ramaekers FCS, Twijnstra A.

The value of interphase cytogenetics in cytology for the diagnosis of leptomeningeal metastases.

Neurology 1998;51:906-908.

Van Oostenbrugge RJ, Hopman AHN, Ramaekers FCS, Twijnstra A.

In situ hybridization: A possible diagnostic aid in leptomeningeal metastasis.

J Neurooncol 1998;38:127-133.

Van Rijswijk REN, Van Oostenbrugge RJ, Twijnstra A.

A case of brain metastases from male breast cancer responding to tamoxifen.

Eur J Cancer 1997;33:2282-2283.

Van Oostenbrugge RJ, Arends JW, Buchholtz R, Twijnstra A.

Cytology of cerebrospinal fluid. Are polylysine-coated slides useful?

Acta Cytol 1997;41:1510-1512.

Van Oostenbrugge RJ, Hopman AHN, Lenders MH, Van Heerde P, Arends JW, Ramaekers FCS, Twijnstra A.

Detection of malignant cells in cerebrospinal fluid using fluorescence in situ hybridization. J Neuropathol Exp Neurol 1997;56:743-748.

Van Oostenbrugge RJ, Freling G, Lodder J, Lalisang R, Twijnstra A.

Fatal stroke due to paradoxical fat embolism.

Cerebrovasc Dis 1996;6:313-314.

Dubbeld P, Van Oostenbrugge RJ, Twijnstra A, Schouten HC.

Spinal epidural abscess due to Aspergillus infection of the vertebrae: report

of 3 cases.

Neth J Med 1996;48:18-23.

Van Oostenbrugge RJ, Vles JSH.

Posture in low-risk pre-term infants of 30 weeks postmenstrual age.

Brain Dev 1995;17:253-255.

Ten Tusscher MPM, Houtman AC, Van Oostenbrugge RJ, Wilmink JT.

Oculofacial paralysis with simultaneous bilateral abduction in Bell's phenomenon and bilateral disc colobomas.

Neuro-ophthalmology 1993;13:297-302. 
Van Kranen-Mastenbroek V, Van Oostenbrugge R, Palmans L, Stevens A, Kingma H, Blanco C, Hasaart T, Vles J.

Inter- and intra-observer agreement in the assessment of the quality of spontaneous movements in the newborn.

Brain Dev 1992;14:289-293.

Vles JSH, Van Oostenbrugge RJ, Hasaart THM, Caberg H, Kingma H, Casaer PJM, Blanco CE.

State profile in low-risk pre-term infants: a longitudinal study of 7 infants from 32-36 weeks of postmenstrual age.

Brain Dev 1992;14:12-17.

Vles JSH, Van Oostenbrugge R, Kingma H, Caberg H, Casaer P.

Posture during head turning in pre-term infants: a longitudinal study of 15 low-risk infants of 32-36 weeks of conceptional age.

Neuropediatrics 1989;20:25-29.

Vles JSH, Van Oostenbrugge R, Kingma H, Caberg H, Casaer P.

Head position in low-risk premature infants. Impact of nursing routines.

Biol Neonate 1988;54:307-313.

Vles JSH, Van Oostenbrugge R, Kingma H, Caberg H, Casaer P.

Influence of head position and head position-change on body posture in pre-term infants (A.T.N.R.).

Neuropediatrics 1988;19:96-100. 
Financial support was also provided by Schering-Plough BV, Biogen BV, Byk Nederland BV, Schering Nederland BV, Glaxo Wellcome BV, Roche Nederland BV, Eli Lilly Nederland BV, Ipsen Farmaceutica BV, Yamanouchi Pharma. 

Leptomeningeal metastases (LMM) are a serious complication of systemic cancer which can cause severe neurological sequelae. It is impoitant to diagnose LMM as early as possible, because early treatment of LMM can prevent these sequelae, it is generally accepted that a definitive diagnosis can be made by the detection of malignant cells in the cerebrospinal fluid (CSF).

However, CSF cytology is only moderately sensitive. In order to improve the diagnostic assessment of patients with IMM we performed several studies, described in this thesis. After establishing the additional diagnostic value of clinical features and of some routine dlagnostic tests, we studied the diagnostic value of interphase cytogenetics. This method allows us to visualize chromosomal aberrations in interphase nuclei based on in situ hybridization (ISH) with labeled DNA probes, After demonstrating the feaslbility of applylng this method to cells from CSF, we showed that the trimor cells in the CSF did Indeed represent the LMM, as they had the identical genetic contents. The ISH method was then studied for its clinical relevance in patients with LMM. We demonstrated that the ISH techinique was of additional dlagnostic value in patients clinically suspected of LMM. and that the response fo therapy for LMM could be monitored more accurately bith this technique. We conclude that the use of the iSH technique has the potentfal to become an important diagnostic test in the assessment of patients with thM. 